\title{
Surface-treated commercially pure titanium for biomedical applications: Electrochemical, structural, mechanical and chemical characterizations
}

\author{
Erika S. Ogawa a,b ${ }^{\mathrm{a}}$, Adaias O. Matos ${ }^{\mathrm{a}, \mathrm{b}}$, Thamara Beline ${ }^{\mathrm{a}, \mathrm{b}}$, Isabella S.V. Marques ${ }^{\mathrm{a}}$, Cortino Sukotjo ${ }^{\mathrm{c}, \mathrm{d}}$,

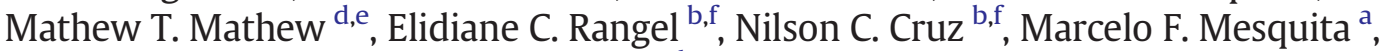 \\ Rafael X. Consani ${ }^{a}$, Valentim A.R. Barão ${ }^{\mathrm{a}, \mathrm{b}, *}$ \\ a Department of Prosthodontics and Periodontology, Piracicaba Dental School, University of Campinas (UNICAMP), Av Limeira, 901, Piracicaba, São Paulo 13414-903, Brazil \\ ${ }^{\mathrm{b}}$ IBTN/Br-Institute of Biomaterials, Tribocorrosion and Nanomedicine-Brazilian Branch, Brazil \\ ' Department of Restorative Dentistry, University of Illinois at Chicago, College of Dentistry, 801 S Paulina, Chicago, IL, USA, 60612 \\ d IBTN-Institute of Biomaterials, Tribocorrosion and Nanomedicine, USA \\ e Department of Biomedical Sciences, University of Illinois, College of Medicine at Rockford, 1601 Parkview Avenue, Rockford, IL, USA, 61107 \\ ${ }^{\mathrm{f}}$ Laboratory of Technological Plasmas, Engineering College, Univ Estadual Paulista (UNESP), Av Três de Março, 511, Sorocaba, São Paulo 18087-180, Brazil
}

\section{A R T I C L E I N F O}

\section{Article history:}

Received 13 November 2015

Received in revised form 17 March 2016

Accepted 11 April 2016

Available online 16 April 2016

\section{Keywords:}

Titanium

Corrosion

Electrochemistry

Electrochemical impedance spectroscopy

Dental implant

X-ray diffraction

\begin{abstract}
A B S T R A C T
Modified surfaces have improved the biological performance and biomechanical fixation of dental implants compared to machined (polished) surfaces. However, there is a lack of knowledge about the surface properties of titanium (Ti) as a function of different surface treatment. This study investigated the role of surface treatments on the electrochemical, structural, mechanical and chemical properties of commercial pure titanium (cp-Ti) under different electrolytes. Cp-Ti discs were divided into 6 groups $(n=5)$ : machined (M-control); etched with $\mathrm{HCl}+\mathrm{H}_{2} \mathrm{O}_{2}(\mathrm{Cl}), \mathrm{H}_{2} \mathrm{SO}_{4}+\mathrm{H}_{2} \mathrm{O}_{2}(\mathrm{~S})$; sandblasted with $\mathrm{Al}_{2} \mathrm{O}_{3}(\mathrm{Sb}), \mathrm{Al}_{2} \mathrm{O}_{3}$ followed by $\mathrm{HCl}+\mathrm{H}_{2} \mathrm{O}_{2}(\mathrm{SbCl})$, and $\mathrm{Al}_{2} \mathrm{O}_{3}$ followed by $\mathrm{H}_{2} \mathrm{SO}_{4}+\mathrm{H}_{2} \mathrm{O}_{2}(\mathrm{SbS}$ ). Electrochemical tests were conducted in artificial saliva (pHs 3; 6.5 and 9) and simulated body fluid (SBF-pH 7.4). All surfaces were characterized before and after corrosion tests using atomic force microscopy, scanning electron microscopy, energy dispersive microscopy, X-ray diffraction, surface roughness, Vickers microhardness and surface free energy. The results indicated that $\mathrm{Cl}$ group exhibited the highest polarization resistance $\left(\mathrm{R}_{\mathrm{p}}\right)$ and the lowest capacitance $(\mathrm{Q})$ and corrosion current density $\left(\mathrm{I}_{\text {corr }}\right)$ values. Reduced corrosion stability was noted for the sandblasted groups. Acidic artificial saliva decreased the $R_{p}$ values of cp-Ti surfaces and produced the highest $I_{\text {corr }}$ values. Also, the surface treatment and corrosion process influenced the surface roughness, Vickers microhardness and surface free energy. Based on these results, it can be concluded that acid-etching treatment improved the electrochemical stability of cp-Ti and all treated surfaces behaved negatively in acidic artificial saliva.
\end{abstract}

(c) 2016 Elsevier B.V. All rights reserved.

\section{Introduction}

Dental implants have been widely used to rehabilitate partial and complete edentulous patients [1-3]. Commercially pure titanium (cp$\mathrm{Ti}$ ) is the most common material used to fabricate dental implants due to its appropriate mechanical strength and biocompatibility [4-7]. However, it is scientifically known that titanium (Ti) can degrade/corrode when exposed to chemicals such as acid, fluoride and saliva [8-10]. The oral fluids may induce the formation of corrosion cracks at the abutment/implant interface [11]. Besides, the $\mathrm{pH}$ around dental implants can vary [8] where certain food such as nuts and milk can alkaline saliva [12]. Sugary foods, some fruits, pickled foods, or even infections, chronic diseases and smoking habits can acidify saliva [12-14] leading to the

\footnotetext{
* Corresponding author at: Av. Limeira, 901, Piracicaba, SP 13414-903, Brazil. E-mail address: vbarao@unicamp.br (V.A.R. Barão).
}

formation of corrosion products. Barao et al. [9] reported reduced corrosion resistance of machined $\mathrm{cp}-\mathrm{Ti}$ and $\mathrm{Ti}-6 \mathrm{Al}-4 \mathrm{~V}$ alloy in acidic media.

The process of corrosion can affect the mechanical properties, biocompatibility and function of dental implants, which may lead to their failure $[8,15,16]$. The abnormal electrical currents produced during corrosion, convert dental implants into an electrode, and the negative impact on the surrounding tissue could be an additional cause of implant failure [16].

Several methods of surface treatment have been suggested, including additional techniques to create projections on implant surface [17-19] as well as subtraction techniques to create pores and pits on implant surface [20-22]. Acid etching has been used for cleaning and decontamination of Ti surface besides changing its physical-chemical properties [23,24]. Prolonged treatment with hydrogen peroxide $\left(\mathrm{H}_{2} \mathrm{O}_{2}\right)$ is an alternative for deposition of apatite on Ti surface to improve its bioactivity [25]. A method combining sulfuric acid $\left(\mathrm{H}_{2} \mathrm{SO}_{4}\right)$ and $\mathrm{H}_{2} \mathrm{O}_{2}$ has been suggested to control the chemical deoxidation/ 
reoxidation of Ti-based materials and promote a clean surface with a reproducible oxide layer for covalent immobilization of bioactive molecules [26]. Furthermore, the chemical treatment of Ti with $\mathrm{H}_{2} \mathrm{O}_{2}$ and hydrochloric acid $(\mathrm{HCl})$ is a simple method to provide bone formation, apatite deposition for better osteoconductivity and proliferative abilities [27-29]. In addition, this treatment creates a gel layer of bioactive Ti on complex surfaces [27].

Sandblasting is a common method for treatment of Ti surface that increases the adhesion of osteoblasts in biological environment [30] and improves osseointegration of dental implants. The positive effect of sandblasting was previously associated to an increased roughness on implant surface [31]. However, it was recently suggested that Ti osseointegration also results from negative polarized high electrical charge on material surface [32]. Therefore, the method to combine sandblasting with large particles and acid etching (SLA) has become a common implant surface treatment [33]. Clinically, these implant surfaces created an increased deposition of bone tissue in histomorphometric analysis and high removal torque values in biomechanical studies [28]. In general, modified surface improves the biological performance and biomechanical fixation of dental implants compared to machined surfaces $[34,35]$.

Zhang et al. [36] reported reduced corrosion resistance of sandblasted, and sandblasted and large-grits acid etching (SLA) of Ti-10Cu alloy. Also, Faverani et al. [37] observed poor corrosion behavior of $\mathrm{Ti}-6 \mathrm{Al}-4 \mathrm{~V}$ alloy treated with $\mathrm{Al}_{2} \mathrm{O}_{3}$ sandblasting. On the other hand, sandblasting associated with oxalic acid etching improves the electrochemical properties of $\mathrm{Ti}$ [38].

The role of the different surface treatments on the corrosion behavior of Ti is still under study. There is no study that comprehensively and systematically evaluated the electrochemical stability of several clinically relevant implant surfaces, which mimic the real implants used in patients. Further, the corrosion kinetics of those surfaces investigated in different electrolytes has been weakly explored as well. Therefore, the objective of this study was to investigate the influence of different surface treatment protocols on the electrochemical stability of $\mathrm{cp}$-Ti in artificial saliva (pHs 3; 6.5 and 9) and simulated body fluid (SBF) (pH 7.4). The structural (surface roughness, wettability, surface free energy, crystalline composition of oxides, microstructure, and topography), mechanical (microhardness), and chemical (energy dispersive spectroscopy) properties of cp-Ti were also evaluated. Our research hypotheses were (i) clinically used surface modifications would improve the electrochemical stability and surface properties of cp-Ti, and (ii) the electrolyte types would drive the corrosion behavior of $\mathrm{cp}-\mathrm{Ti}$.

\section{Materials and methods}

\subsection{Cp-Ti discs}

Cp-Ti discs (grade II) with $15 \mathrm{~mm}$ in diameter and $2 \mathrm{~mm}$ in thickness (MacMaster Carr, Elmhurst, IL, USA) were divided into 6 groups $(n=5)$ as a function of different surfaces treatment: machined (M group) (control); etched with hydrochloric acid + hydrogen peroxide $(\mathrm{Cl}$ group); etched with sulfuric acid + hydrogen peroxide (S group); sandblasted with aluminum oxide (Sb group); sandblasted with aluminum oxide and etched with hydrochloric acid + hydrogen peroxide (SbCl group); and sandblasted with aluminum oxide and etched with sulfuric acid + hydrogen peroxide (SbS group).

\subsection{Samples preparation}

All discs were polished with sequential grid sandpapers (\#320, \#400, \#600) (Carbimet 2, Buehler, Lake Bluff, IL, USA) in an automatic polisher (EcoMet 300 Pro with AutoMet 250; Buehler, Lake Bluff, IL, USA). The samples were ultrasonically cleaned with deionized water (10 min) and 70\% propanol (10 min) (Sigma-Aldrich, St. Louis, MO, USA) and dried with warm air at $250{ }^{\circ} \mathrm{C}$ [9].

\subsection{Surface treatment protocols}

The M group was obtained by mechanical polishing, as previously described in Section 2.2. Samples from the $\mathrm{Cl}$ group were etched with a solution containing $0.1 \mathrm{~mol} / \mathrm{L}$ of $\mathrm{HCl}$ and $8.8 \mathrm{~mol} / \mathrm{L}$ of $\mathrm{H}_{2} \mathrm{O}_{2}$ (Sigma-Aldrich, St. Louis, MO, USA) at $80{ }^{\circ} \mathrm{C}$ during $20 \mathrm{~min}$. Then, the samples were washed with distilled water, oven dried at $50{ }^{\circ} \mathrm{C}$ for $12 \mathrm{~h}$, heated with air at $400{ }^{\circ} \mathrm{C}$ for $1 \mathrm{~h}$, and cooled in an electrical oven [27]. At the end, the discs were washed with distilled water and vacuum dried. In the S group, discs were washed with toluene (Sigma-Aldrich, St. Louis, MO, USA) and chemically treated with a solution containing equal volumes of $\mathrm{H}_{2} \mathrm{SO}_{4}$ concentrated (Sigma-Aldrich, St. Louis, MO, USA) and an aqueous solution of $30 \% \mathrm{H}_{2} \mathrm{O}_{2}$ (Sigma-Aldrich, St. Louis, MO, USA) at $25^{\circ} \mathrm{C}$ for $2 \mathrm{~h}$. Then, the discs were washed with distilled water and vacuum dried $[23,39]$. In the Sb group, discs were sandblasted with $150 \mu \mathrm{m}$ particles of $\mathrm{Al}_{2} \mathrm{O}_{3}$ (Polidental Indústria Comércio Ltd, Cotia, São Paulo, Brazil) deposited at $50 \mathrm{~mm}$ of distance with $90^{\circ}$ of angulation using $0.45 \mathrm{MPa}$ pressure during $30 \mathrm{~s}$ [33]. Then, the discs were rinsed in ultrasonic tank containing distilled water for $15 \mathrm{~min}$ and dried at room temperature $\left(23{ }^{\circ} \mathrm{C}\right)$. For the $\mathrm{SbCl}$ and $\mathrm{SbS}$ groups, the discs were sandblasted and then acid etched with $\mathrm{HCl}+\mathrm{H}_{2} \mathrm{O}_{2}$ and $\mathrm{H}_{2} \mathrm{SO}_{4}+\mathrm{H}_{2} \mathrm{O}_{2}$, respectively.

\subsection{Electrochemical test}

The electrochemical tests were performed using a potentiostat (Interface 1000, Gamry Instruments, Warminster, PA, USA) for the corrosion measurements in an electrochemical cell made of polysulfone. All measurements were performed on a standardized method of threeelectrode cell in accordance with the instructions of the American Society for Testing of Materials (ASTM) (G61-86 and G31-72). A saturated calomel electrode (SCE) was used as a reference electrode (RE), a graphite rod as a counter electrode (auxiliary) (CE) and the exposed surface of $\mathrm{cp}$-Ti disc as a working electrode (WE). A total of $10 \mathrm{~mL}$ of electrolyte (artificial saliva or simulated body fluid) was used for each corrosion experiment. The electrolyte temperature was maintained at $37 \pm 1{ }^{\circ} \mathrm{C}$ and different pH levels of artificial saliva (3; 6.5 and 9) were used to mimic the oral environment and the simulated body fluid (SBF) was used to simulate the blood plasma ( $\mathrm{pH}=7.4$ ).

The chemical composition for the artificial saliva was $\mathrm{KCl}(0.4 \mathrm{~g} / \mathrm{L})$, $\mathrm{NaCl}(0.4 \mathrm{~g} / \mathrm{L}), \mathrm{CaCl}_{2} \cdot 2 \mathrm{H}_{2} \mathrm{O}(0.906 \mathrm{~g} / \mathrm{L}), \mathrm{NaH}_{2} \mathrm{PO}_{4} \cdot 2 \mathrm{H}_{2} \mathrm{O}(0.690 \mathrm{~g} / \mathrm{L})$, $\mathrm{Na}_{2} \mathrm{~S} \cdot 9 \mathrm{H}_{2} \mathrm{O}(0.005 \mathrm{~g} / \mathrm{L})$, and urea $(1.0 \mathrm{~g} / \mathrm{L})(8,46)$. Different $\mathrm{pH}$ values were achieved by adding lactic acid (acidic) or $\mathrm{NaOH}$ (basic) in an appropriate amount and evaluated in a $\mathrm{pH}$ meter. The composition of the SBF was $\mathrm{NaCl}(12.0045 \mathrm{~g} / \mathrm{L}), \mathrm{NaHCO}_{3}(0.5025 \mathrm{~g} / \mathrm{L}), \mathrm{KCl}$ $(0.3360 \mathrm{~g} / \mathrm{L}), \mathrm{K}_{2} \mathrm{HPO}_{4}(0.2610 \mathrm{~g} / \mathrm{L}), \mathrm{Na}_{2} \mathrm{SO}_{4}(0.1065 \mathrm{~g} / \mathrm{L}), 1 \mathrm{M} \mathrm{HCl}$ $(60 \mathrm{~mL}), \mathrm{CaCl}_{2} \cdot 2 \mathrm{H}_{2} \mathrm{O}(0.5520 \mathrm{~g} / \mathrm{L}), \mathrm{MgCl}_{2} \cdot \mathrm{H}_{2} \mathrm{O}(0.4575 \mathrm{~g} / \mathrm{L})$. Tris was used to achieve a $\mathrm{pH}$ of 7.4 [40].

The exposed area of the disc was estimated by atomic force microscopy (AFM) analysis for all groups $\left(\mathrm{M}=2.04 \mathrm{~cm}^{2}, \mathrm{Cl}=2.31 \mathrm{~cm}^{2}, \mathrm{~S}=\right.$ $\left.2.32 \mathrm{~cm}^{2}, \mathrm{Sb}=2.44 \mathrm{~cm}^{2} ; \mathrm{SbCl}=2.47 \mathrm{~cm}^{2} ; \mathrm{SbS}=2.46 \mathrm{~cm}^{2}\right)$. Initially, the discs were subjected to a cathodic potential $(-0.9 \mathrm{~V}$ vs. SCE) to standardize the starting conditions. Over a period of $3600 \mathrm{~s}$, the open circuit potential (OCP) was monitored to evaluate the free corrosion potential of the material surface in the electrolyte solution. The electrochemical impedance spectroscopy (EIS) was used to investigate the oxide layer of cp-Ti surfaces and its properties (corrosion kinetics). Measurements of the EIS were made at a frequency of $100 \mathrm{kHz}$ to $5 \mathrm{mHz}$, with AC curve in a range of $\pm 10 \mathrm{mV}$ applied to the electrode at its corrosion potential. The values were used to determine the real $\left(Z^{\prime}\right)$ and imaginary $\left(Z^{\prime \prime}\right)$ components of impedance, which were used to construct Nyquist, Bode $(|Z|)$ and phase angle plots. Through EIS data, an equivalent electrical circuit was proposed to represent the electrochemical process and oxide layer properties in order to quantify the corrosion process $\left(R_{p}-\right.$ polarization resistance and CPE-constant phase element). The EIS data were analyzed using Echem Analyst Software 
(Gamry Instruments, Warminster, PA, USA). Finally, the samples were polarized from $-0.8 \mathrm{~V}$ to $1.8 \mathrm{~V}$ ( $2 \mathrm{mV} / \mathrm{s}$ scan rate) [8,9,41]. Corrosion parameters such as $\mathrm{E}_{\text {corr }}$ (corrosion potential), $\mathrm{I}_{\text {corr }}$ (corrosion current density), and Tafel slopes ( $b c, b a$ ) were obtained from the polarization curves by Tafel extrapolation method using electrochemical software (Echem Analyst Software, Gamry Instruments, Warminster, PA, USA).

The electrochemical tests were conducted at least five times $(n=5)$ to ensure reliability and reproducibility.

\subsection{Surface characterization}

\subsubsection{Surface roughness}

The cp-Ti surface roughness Ra (arithmetical mean of surface roughness) was measured using a perfilometer (Dektak 150-d; Veeco, Plainview, NY, USA) at baseline and after corrosion experiments $(n=5)$. The values of Ra were calculated with cut-off of $0.25 \mathrm{~mm}$ at $0.05 \mathrm{~mm} / \mathrm{s}$ during $12 \mathrm{~s}$. For each disc, three measurements were obtained including one at the center, one at the right side, and one at the left side.

\subsubsection{Vickers microhardness}

The Vickers microhardness of the cp-Ti discs $(n=5)$ was evaluated by an indenter (Shimadzu, HMV-2 Micro Hardness Tester, Shimadzu Corporation, Kyoto, Japan). Data were collected in an environment with controlled temperature $\left(22 \pm 2{ }^{\circ} \mathrm{C}\right)$ applying a load of $500 \mathrm{gf}$ during $15 \mathrm{~s}$. The Vickers hardness units (VHN) were calculated according to the following formula:

VHN $2 \mathrm{P}=\sin \left(136^{\circ} / 2\right) / \mathrm{d} 2$

where $\mathrm{P}=$ load and $\mathrm{d}=$ diagonal length of indentations.
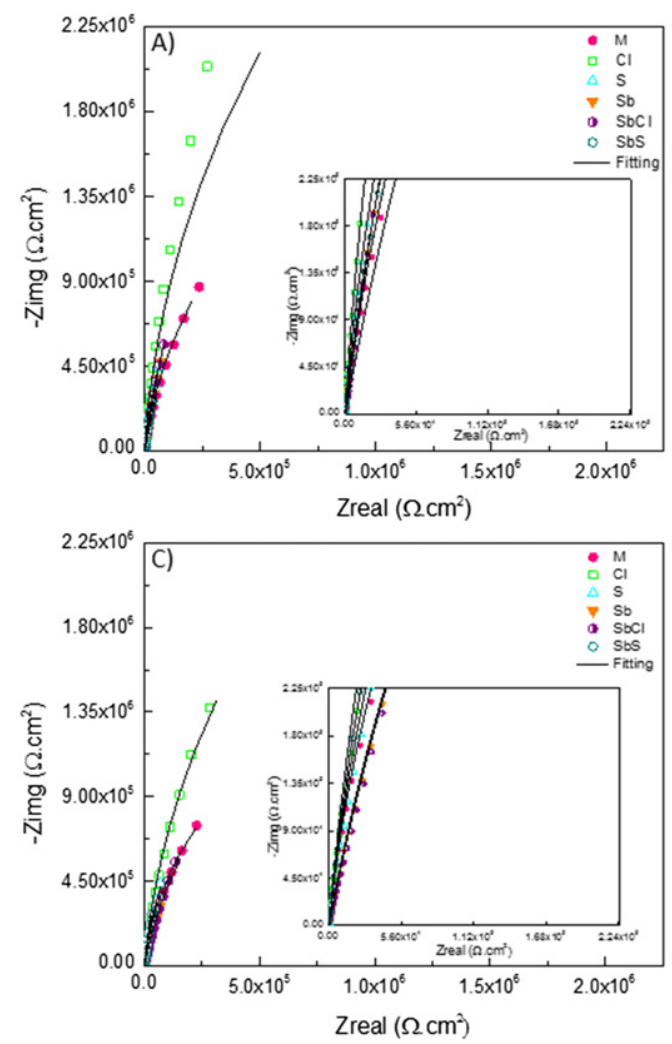

The test was repeated in four randomly selected points on the disc surface before (baseline) and after the corrosion process $(n=5)$. The mean values represented the Vickers microhardness value.

\subsubsection{Surface free energy}

The surface free energy of the cp-Ti discs before and after corrosion process $(n=5)$ was measured with a goniometer (Ramé-Hart 10000; Ramé-Hart Instrument Co, Succasunna, NJ, USA) according to the sessile drop method. The water (polar component) and diiodomethane (disperse component) contact angles were calculated. The contact angle was calculated according to the Young equation:

$\mathrm{Y}_{\mathrm{sv}}=\mathrm{Y}_{\mathrm{s} 1}+\mathrm{Y}_{1 \mathrm{v}} \cos \Theta_{\mathrm{c}}$

${ }^{*} \Theta_{c}=$ contact angle, $Y$ $=$ surface energy of solid in equilibrium with vapor (sv), solid in equilibrium with liquid (sl), and liquid in equilibrium with vapor (lv).

The relation between contact angle and surface energy was evaluated through the Owens-Wendt method, based on the contact angle of liquids with different polarities.

\subsubsection{Atomic force microscopy}

Atomic force microscopy (AFM; 5500 AFM/SPM, Agilent Technologies, Chandler, AZ, USA) was used to evaluate the 2D and 3D surface topographies of the samples. Images with $5 \times 5 \mu^{2}$ were obtained in tapping mode and two areas of the disc were selected for analysis. An appropriate software (Gwyddion v 2.37; GNU General Public License; Czech Republic) was used for image processing.

2.5.5. Scanning electron microscopy and energy dispersive spectroscopy

Scanning electron microscopy (SEM; JEOL JSM-6010LA, Peabody, MA, USA) was used to observe the morphologies of machined and treated cp-Ti surfaces. The images were obtained at $950 \times$ magnification. The chemical composition of the $\mathrm{cp}$-Ti discs was evaluated through energy
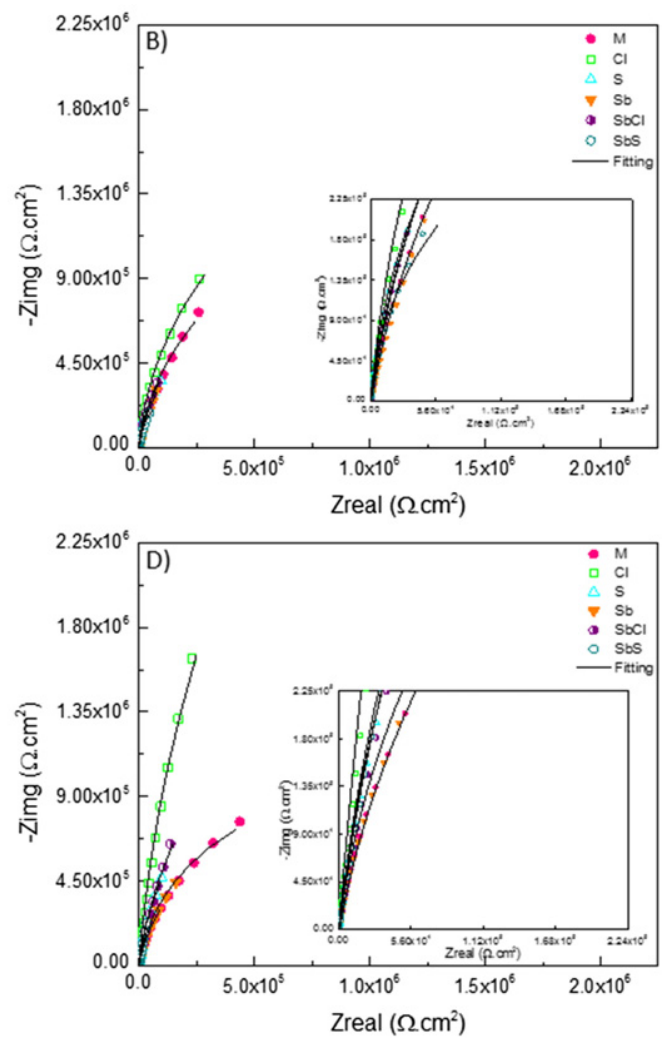

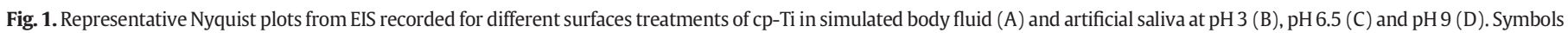
represent experimental data and solid lines fitted data. 

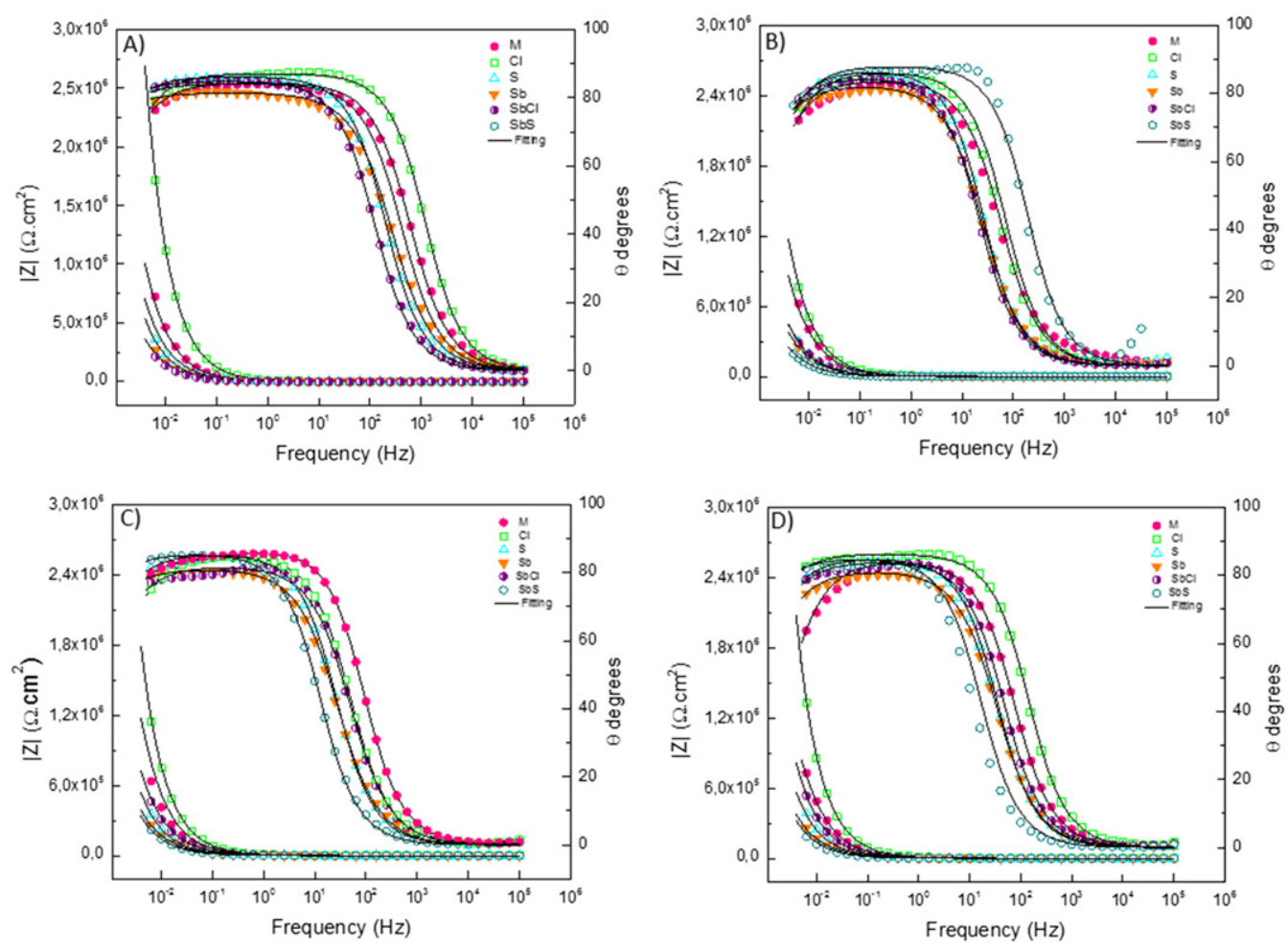

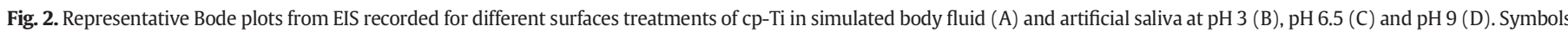
represent experimental data and solid lines fitted data.

dispersive spectroscopy (EDS) attached to the scanning electron microscope.

\subsubsection{X-ray diffraction}

The phase composition of the surfaces was determined by an X-ray diffractometer (XRD; Panalytical, $X^{\prime}$ Pert $^{3}$ Powder, Almelo, The Netherlands) using $\mathrm{Cu} \mathrm{K} \alpha$ ( $\lambda=1.540,598 \AA$ ) , $45 \mathrm{kV}, 40 \mathrm{~mA}$, and continuous speed of 0.05 per second.

\subsection{Statistical analysis}

Two-way ANOVA was used to explore the effects of the different surfaces (factor 1) and electrolytes (factor 2) on the corrosion behavior of the $\mathrm{cp}$ - Ti (CPE (represented by Q), $\mathrm{R}_{\mathrm{p}}, \mathrm{I}_{\text {corr }}$ and $\mathrm{E}_{\text {corr }}$ ), roughness (Ra), Vickers microhardness and surface free energy data. Tukey HSD test was used as a post-hoc test. All analyses were performed at a significance level of 5\% (SPSS v.20.0, SPSS Inc., IBM Corp, Armonk, NY, USA). The sample size of each test was statistically determined to achieve a large effect according to Cohen's effect size $(>0.8)$ and Partial Eta Squared $\left(\eta_{\mathrm{p}}^{2}>0.26\right)$ analyses.

\section{Results}

\subsection{EIS measurements}

The Nyquist plot in Fig. 1, presents the evolution of resultant impedance as a function of real and imaginary components (Zreal vs Zimg). Bode plots (Fig. 2) provide the variation of impedance as a function of frequency of the electrochemical double layer formed at the interface of Ti during corrosion process (corrosion kinetics). The Nyquist plots demonstrate the electrochemical resistance of Ti surface. Part of the graph was magnified in order to visualize the groups due to the difference of magnitude in the Zreal and Zimaginary. The $\mathrm{Cl}$ group presented the highest semicircular diameter of capacitance loop for all electrolytes tested, evidencing its increased corrosion stability. Regardless of cp-Ti surface, samples immersed in acidic artificial saliva had a decrease of the semicircular diameter of capacitance loop, which means inferior corrosion resistance.

In the phase angle of bode plots, just one time constant was observed for groups in all electrolytes, which indicates the presence of compact, homogeneous and protective passive film. At high frequency, both phase angles and total impedance modulus $|\mathrm{Z}|$ were low. By decreasing the frequency, the $|Z|$ steadily increased with the increment in phase angle. At low frequencies, the increase in $|Z|$ values suggests the improvement of electrochemical stability. Sandblasted groups associated or not with acid etching had the lowest $|\mathrm{Z}|$ value while $\mathrm{Cl}$ and $\mathrm{M}$ groups exhibited the greatest one. The phase angle for $\mathrm{cp}$-Ti in acidic media exhibited the lowest angle value, which characterizes poorest corrosion resistance of $\mathrm{cp}-\mathrm{Ti}$ in artificial saliva at low $\mathrm{pH}$. It was mainly noted for sandblasted groups ( $\mathrm{Sb}, \mathrm{SbCl}$ and $\mathrm{SbS}$ ).

A simple equivalent circuit with a parallel resistance-capacitance $\left(R_{p}-C P E\right)$ in series with the resistance of solution ( $\left.R_{\text {sol }}\right)$ (Fig. 3) was used to simulate the electrical parameters of the surface. In this circuit, $R_{\text {sol }}$ represents the resistance of the electrolyte, $R_{p}$ is the polarization resistance and CPE (constant phase element) is the specific double-layer capacitance at the working electrode/electrolyte interface. CPE works as an imperfect capacitor due to the surface heterogeneities, such as roughness [42]. The chi-square $\left(\chi^{2}\right)$ values on the order of $10^{-3}$ were obtained, which indicates the good quality of fitting with the data well adjusted to the proposed equivalent circuit (Table 1 ).

$\mathrm{R}_{\mathrm{p}}$ and CPE (represented as $\mathrm{Q}$ ) data are shown in Table 1. Lower $\mathrm{Q}$ values and higher $R_{p}$ values indicate higher corrosion resistance. In

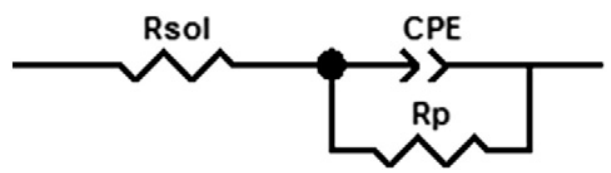

Fig. 3. Equivalent electrical circuit used to EIS data. 
Table 1

Mean and standard deviation ( $n=5$ ) of electrical parameters obtained from the equivalent circuit model for all groups.

\begin{tabular}{|c|c|c|c|c|c|}
\hline Groups & Electrolytes & $\mathrm{R}_{\mathrm{p}}\left(\mathrm{m} \Omega \mathrm{cm}^{-2}\right)$ & $\begin{array}{l}\mathrm{Q}\left(\mathrm{W}^{-1} \mathrm{~S}^{\mathrm{n}}\right. \\
\left.\mathrm{cm}^{-2}\right) \times 10^{-5}\end{array}$ & $\eta$ & $\chi^{2} \times 10^{-3}$ \\
\hline \multirow{4}{*}{ M } & SBF & $3.68 \pm 0.87^{\mathrm{aA}}$ & $3.03 \pm 0.07^{\mathrm{aA}}$ & $0.93 \pm 0.00$ & $1.11 \pm 0.45$ \\
\hline & AS 3.0 & $2.56 \pm 0.93^{\mathrm{aA}}$ & $3.60 \pm 0.24^{\mathrm{aA}}$ & $0.94 \pm 0.01$ & $2.15 \pm 0.11$ \\
\hline & AS 6.5 & $3.11 \pm 1.13^{\mathrm{aA}}$ & $3.49 \pm 0.29^{\mathrm{aA}}$ & $0.94 \pm 0.00$ & $0.75 \pm 0.50$ \\
\hline & AS 9.0 & $2.34 \pm 0.54^{\mathrm{aA}}$ & $2.64 \pm 0.17^{\mathrm{aA}}$ & $0.93 \pm 0.00$ & $0.63 \pm 0.00$ \\
\hline \multirow{4}{*}{$\mathrm{Cl}$} & SBF & $3.68 \pm 1.07^{\mathrm{aA}}$ & $1.67 \pm 0.44^{\mathrm{bA}}$ & $0.96 \pm 0.01$ & $0.40 \pm 0.19$ \\
\hline & AS 3.0 & $3.36 \pm 0.60^{\mathrm{aA}}$ & $2.85 \pm 0.18^{\mathrm{aB}}$ & $0.95 \pm 0.01$ & $0.13 \pm 0.07$ \\
\hline & AS 6.5 & $6.84 \pm 2.46^{\mathrm{bB}}$ & $1.73 \pm 0.15^{\mathrm{bA}}$ & $0.95 \pm 0.01$ & $0.33 \pm 0.18$ \\
\hline & AS 9.0 & $2.27 \pm 0.58^{\mathrm{aA}}$ & $1.55 \pm 0.14^{\mathrm{aA}}$ & $0.95 \pm 0.01$ & $3.12 \pm 0.51$ \\
\hline \multirow{4}{*}{ S } & SBF & $6.15 \pm 0.49^{\mathrm{bA}}$ & $6.18 \pm 0.31^{\mathrm{cdA}}$ & $0.95 \pm 0.01$ & $0.36 \pm 0.10$ \\
\hline & AS 3.0 & $1.58 \pm 0.23^{\mathrm{aB}}$ & $7.37 \pm 0.41^{\mathrm{bB}}$ & $0.96 \pm 0.01$ & $0.62 \pm 0.06$ \\
\hline & AS 6.5 & $3.78 \pm 0.54^{\mathrm{acc}}$ & $6.18 \pm 0.15^{\mathrm{cA}}$ & $0.95 \pm 0.01$ & $0.30 \pm 0.02$ \\
\hline & AS 9.0 & $4.77 \pm 1.13^{\mathrm{bcAC}}$ & $5.60 \pm 0.17^{\mathrm{bA}}$ & $0.95 \pm 0.01$ & $0.36 \pm 0.21$ \\
\hline \multirow{4}{*}{$\mathrm{Sb}$} & SBF & $1.02 \pm 0.18^{\mathrm{cA}}$ & $7.26 \pm 0.63^{\mathrm{cA}}$ & $0.90 \pm 0.01$ & $1.36 \pm 0.53$ \\
\hline & AS 3.0 & $1.80 \pm 4.22^{\mathrm{aB}}$ & $8.31 \pm 0.89^{\mathrm{bB}}$ & $0.91 \pm 0.01$ & $0.23 \pm 0.07$ \\
\hline & AS 6.5 & $4.77 \pm 1.09^{\mathrm{abc}}$ & $6.81 \pm 0.96^{\mathrm{CA}}$ & $0.89 \pm 0.03$ & $0.35 \pm 0.07$ \\
\hline & AS 9.0 & $1.92 \pm 0.81^{\mathrm{aB}}$ & $6.67 \pm 0.78^{\mathrm{cA}}$ & $0.91 \pm 0.01$ & $0.37 \pm 0.17$ \\
\hline \multirow{4}{*}{$\mathrm{SbCl}$} & SBF & $1.16 \pm 0.23^{\mathrm{cA}}$ & $4.97 \pm 0.44^{\mathrm{dA}}$ & $0.93 \pm 0.01$ & $0.39 \pm 0.14$ \\
\hline & AS 3.0 & $1.95 \pm 0.69^{\mathrm{aB}}$ & $8.25 \pm 1.70^{\mathrm{bB}}$ & $0.92 \pm 0.02$ & $0.23 \pm 0.00$ \\
\hline & AS 6.5 & $3.58 \pm 0.88^{\mathrm{acB}}$ & $3.72 \pm 0.17^{\mathrm{aA}}$ & $0.91 \pm 0.01$ & $0.87 \pm 0.36$ \\
\hline & AS 9.0 & $6.04 \pm 0.80^{\mathrm{bA}}$ & $4.02 \pm 0.68^{\mathrm{dA}}$ & $0.93 \pm 0.01$ & $0.36 \pm 0.08$ \\
\hline \multirow{4}{*}{ SbS } & SBF & $6.37 \pm 1.27^{\mathrm{bA}}$ & $11.6 \pm 1.33^{\mathrm{eAC}}$ & $0.94 \pm 0.01$ & $0.25 \pm 0.12$ \\
\hline & AS 3.0 & $1.20 \pm 0.25^{\mathrm{aB}}$ & $12.8 \pm 2.69^{\mathrm{cB}}$ & $0.96 \pm 0.01$ & $3.01 \pm 0.63$ \\
\hline & AS 6.5 & $5.39 \pm 1.72^{\mathrm{bcAC}}$ & $9.87 \pm 1.56^{\mathrm{dC}}$ & $0.94 \pm 0.01$ & $1.16 \pm 0.17$ \\
\hline & AS 9.0 & $3.50 \pm 0.84^{\mathrm{acC}}$ & $10.7 \pm 5.91^{\mathrm{eC}}$ & $0.95 \pm 0.01$ & $1.49 \pm 0.29$ \\
\hline
\end{tabular}

Means followed by different lowercase letters show statistical difference among the $\mathrm{cp}-\mathrm{T}$ surfaces within each electrolyte type.

Means followed by different capital letters show statistical difference among the electrolytes within each surface type.

general, $\mathrm{Cl}$ group presented the highest and $\mathrm{SbS}$ group the lowest $\mathrm{R}_{\mathrm{p}}$ values $(p<0.05)$. Acidic media tend to reduce the $R_{p}$ values of all surfaces $(p<0.05)$. Following similar trend, $Q$ values were one of the lowest for $\mathrm{Cl}$ group, and the highest for SbS group. Regarding electrolyte

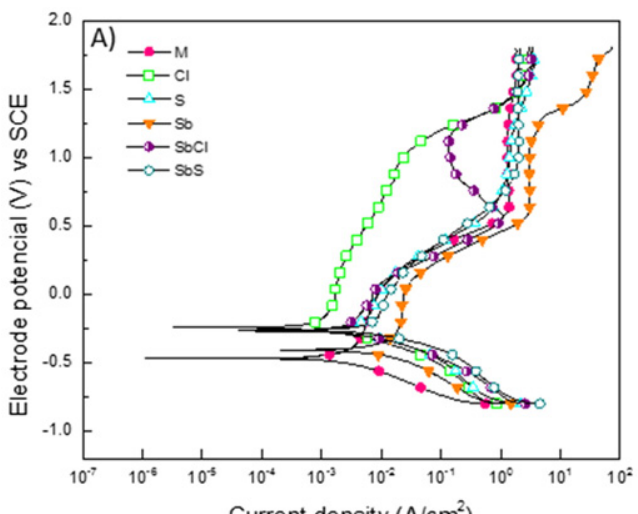

Current density $\left(\mathrm{A} / \mathrm{cm}^{2}\right)$

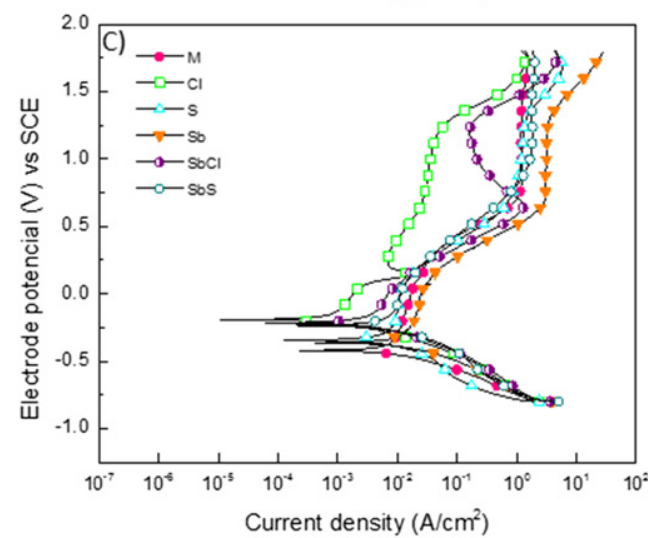

type, artificial saliva at $\mathrm{pH} 3$ increased the $\mathrm{Q}$ values of $\mathrm{cp}$-Ti surfaces (Table 1).

\subsection{Potentiodynamic curves}

The potentiodynamic curves of $\mathrm{cp}$-Ti as a function of surface treatment and electrolyte solution are shown in Fig. 4. The shift of the curves to the left-up area of the graph indicates a more passive character of the samples treated with hydrochloric acid ( $\mathrm{Cl}$ group) in comparison to the other groups. In this group, the current density tends to stabilize between $10^{-3}$ and $10^{-2} \mathrm{~A} / \mathrm{cm}^{2}$ in all electrolytes. The other groups exhibited later current density stability (between 10 and $10^{1} \mathrm{~A} / \mathrm{cm}^{2}$ ). It is interesting to note that sandblasted groups showed depassivation zones at high electrode potential values.

Electrochemical parameters including $\mathrm{I}_{\text {corr }}, \mathrm{E}_{\text {corr }}$, and cathodic Tafel slopes $\left(b_{c}\right)$ obtained from Tafel curves are presented in Table 2 . The Tafel curves of all groups showed no Tafel linear region in the anodic slope $\left(b_{a}\right)$; thus, the parameters were obtained through Tafel extrapolation by using the cathodic slope. Higher $\mathrm{I}_{\text {corr }}$ values indicate less stable oxide layer of the material. $\mathrm{Cl}$ group had the lowest $\mathrm{I}_{\text {corr }}$ values for all electrolytes $(p<0.05)$, while sandblasted groups ( $\mathrm{Sb}, \mathrm{SbCl}$ and $\mathrm{SbS}$ ) showed the highest one. Within each $\mathrm{cp}$-Ti surface, artificial saliva at $\mathrm{pH} 3$ tend to produce the greatest $\mathrm{I}_{\text {corr }}$ values while artificial saliva at $\mathrm{pH} 9$ the lowest one. $\mathrm{E}_{\text {corr }}$ reflects the degree of difficulty of corrosion, where more positive values indicate a better corrosion resistance. Nobler $\mathrm{E}_{\text {corr }}$ values were noted for $\mathrm{Cl}$ group whereas $\mathrm{M}$ and sandblasted groups exhibited more negative values. The studied electrolytes seem to have no influence on the $\mathrm{E}_{\text {corr }}$ values of $\mathrm{cp}$-Ti.

Based on the electrochemical parameters (i.e. $\mathrm{R}_{\mathrm{p}}, \mathrm{Q} \mathrm{I}_{\mathrm{corr}}$ and $\mathrm{E}_{\text {corr }}$ ), $\mathrm{a}$ corrosion map showing the interaction of cp-Ti surface and electrolyte was developed to estimate the electrochemical stability of $\mathrm{cp}-\mathrm{Ti}$ (Fig. 5). It can be seem that $\mathrm{Cl}$ group in artificial saliva at $\mathrm{pH} 9.0$ presented the highest electrochemical stability (dark green zone) while the SbS group in artificial saliva at pH 3.0 showed the worst scenario (dark red
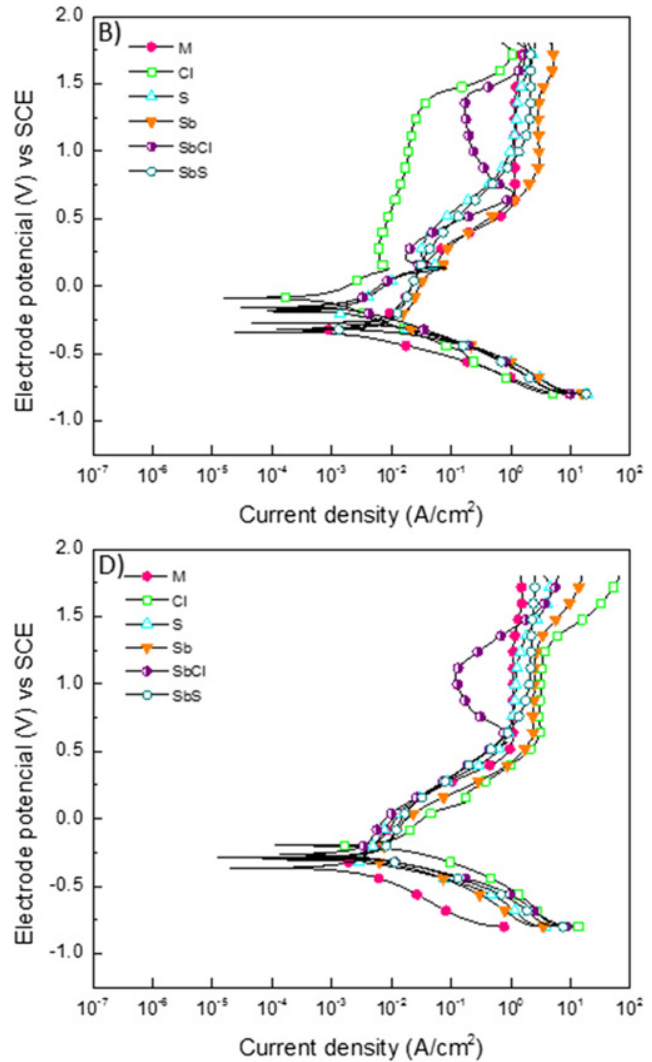

Fig. 4. Representative potentiodynamic curves for different surfaces treatments of cp-Ti in simulated body fluid (A) and artificial saliva at pH 3 (B); pH 6.5 (C) and pH 9 (D). 
Table 2

Mean and standard deviation ( $n=5$ ) values of electrochemical parameters obtained from the potentiodynamic curves using the Tafel slopes.

\begin{tabular}{|c|c|c|c|c|}
\hline Groups & Electrolytes & $-b_{\mathrm{c}}(\mathrm{V} /$ decade $)$ & $\mathrm{I}_{\text {corr }}\left(\mathrm{nA} / \mathrm{cm}^{2}\right)$ & - $\mathrm{E}_{\text {corr }}$ (V vs SCE) \\
\hline \multirow[t]{4}{*}{ M } & SBF & $0.16 \pm 0.01$ & $19.66 \pm 1.41^{\mathrm{acA}}$ & $0.44 \pm 0.02^{\mathrm{aA}}$ \\
\hline & AS 3.0 & $0.13 \pm 0.01$ & $72.7 \pm 22.43^{\mathrm{adB}}$ & $0.43 \pm 0.04^{\mathrm{aA}}$ \\
\hline & AS 6.5 & $0.15 \pm 0.02$ & $15.04 \pm 6.71^{\mathrm{aA}}$ & $0.47 \pm 0.03^{\mathrm{aA}}$ \\
\hline & AS 9.0 & $0.18 \pm 0.01$ & $20.8 \pm 2.82^{\mathrm{aA}}$ & $0.38 \pm 0.03^{\mathrm{acA}}$ \\
\hline \multirow[t]{4}{*}{$\mathrm{Cl}$} & SBF & $0.15 \pm 0.02$ & $12.60 \pm 3.72^{\mathrm{aA}}$ & $0.24 \pm 0.04^{\mathrm{bA}}$ \\
\hline & AS 3.0 & $0.20 \pm 0.01$ & $18.97 \pm 5.81^{\mathrm{bA}}$ & $0.16 \pm 0.05^{\mathrm{bA}}$ \\
\hline & AS 6.5 & $0.22 \pm 0.02$ & $12.98 \pm 3.77^{\mathrm{aA}}$ & $0.12 \pm 0.04^{\mathrm{bA}}$ \\
\hline & AS 9.0 & $0.17 \pm 0.04$ & $13.36 \pm 3.87^{\mathrm{aA}}$ & $0.19 \pm 0.03^{\mathrm{bA}}$ \\
\hline \multirow[t]{4}{*}{ S } & SBF & $0.18 \pm 0.01$ & $35.98 \pm 5.82^{\text {adcA }}$ & $0.26 \pm 0.06^{\mathrm{bA}}$ \\
\hline & AS 3.0 & $0.15 \pm 0.01$ & $39.68 \pm 9.84^{\mathrm{bdA}}$ & $0.20 \pm 0.08^{\mathrm{bA}}$ \\
\hline & AS 6.5 & $0.19 \pm 0.01$ & $35.07 \pm 5.53^{\mathrm{acA}}$ & $0.25 \pm 0.07^{\mathrm{CA}}$ \\
\hline & AS 9.0 & $0.13 \pm 0.02$ & $20.5 \pm 4.46^{\mathrm{aA}}$ & $0.26 \pm 0.04^{\mathrm{bcA}}$ \\
\hline \multirow[t]{4}{*}{$\mathrm{Sb}$} & SBF & $0.21 \pm 0.01$ & $96.18 \pm 25.39^{\mathrm{bA}}$ & $0.39 \pm 0.01^{\mathrm{cA}}$ \\
\hline & AS 3.0 & $0.20 \pm 0.01$ & $144.8 \pm 30.05^{\mathrm{cB}}$ & $0.23 \pm 0.04^{\mathrm{bB}}$ \\
\hline & AS 6.5 & $0.18 \pm 0.01$ & $100.76 \pm 30.66^{\mathrm{bA}}$ & $0.32 \pm 0.03^{\mathrm{caB}}$ \\
\hline & AS 9.0 & $0.17 \pm 0.02$ & $67.58 \pm 40.02^{\mathrm{bC}}$ & $0.26 \pm 0.04^{\text {bсAB }}$ \\
\hline \multirow[t]{4}{*}{$\mathrm{SbCl}$} & SBF & $0.20 \pm 0.04$ & $30.2 \pm 17.66^{\mathrm{acdAB}}$ & $0.24 \pm 0.02^{\mathrm{bA}}$ \\
\hline & AS 3.0 & $0.20 \pm 0.01$ & $54.52 \pm 25.16^{\mathrm{dA}}$ & $0.43 \pm 0.02^{\mathrm{cB}}$ \\
\hline & AS 6.5 & $0.19 \pm 0.01$ & $30.2 \pm 7.81^{\mathrm{acAB}}$ & $0.22 \pm 0.02^{\mathrm{cA}}$ \\
\hline & AS 9.0 & $0.14 \pm 0.01$ & $19.74 \pm 3.40^{\mathrm{aB}}$ & $0.26 \pm 0.01^{\mathrm{bcA}}$ \\
\hline \multirow[t]{4}{*}{ SbS } & SBF & $0.17 \pm 0.01$ & $39.24 \pm 9.08^{\mathrm{ceA}}$ & $0.26 \pm 0.01^{\mathrm{bA}}$ \\
\hline & AS 3.0 & $0.12 \pm 0.01$ & $60.4 \pm 10.75^{\mathrm{dA}}$ & $0.37 \pm 0.02^{\mathrm{acA}}$ \\
\hline & AS 6.5 & $0.19 \pm 0.01$ & $42.16 \pm 12.10^{\mathrm{cA}}$ & $0.20 \pm 0.04^{\mathrm{cB}}$ \\
\hline & AS 9.0 & $0.11 \pm 0.01$ & $61.76 \pm 16.60^{\mathrm{bA}}$ & $0.36 \pm 0.03^{\mathrm{cA}}$ \\
\hline
\end{tabular}

Means followed by different lowercase letters show statistical difference among the cp-Ti surfaces within each electrolyte type.

Means followed by different capital letters show statistical difference among the electrolytes within each surface type.

zone). It is clearly noted that most of the cp-Ti surfaces had increased electrochemical stability in SBF. On the other hand, all surface treatments behaved negatively in artificial saliva at $\mathrm{pH}$ 3.0. Regarding the different surface treatments, machined and etched groups ( $\mathrm{M}, \mathrm{Cl}$ and $\mathrm{S}$ groups) exhibited better electrochemical stability than sandblasted groups ( $\mathrm{Sb}, \mathrm{SbCl}$ and $\mathrm{SbS}$ groups).

\subsection{Surface characterization}

The surface roughness, Vickers microhardness and surface free energy of cp-Ti were affected by the surface treatment and corrosion process. Sandblasted groups ( $\mathrm{Sb}, \mathrm{SbCl}$ and $\mathrm{SbS}$ ) presented the highest Ra values $(p<0.05)$. In the $\mathrm{Cl}$ and $\mathrm{Sb}$ groups, samples showed increased Ra values after exposure in artificial saliva at $\mathrm{pH} 3$ when compared to the baseline values $(p<0.05)$ (Fig. 6). Sandblasting procedure ( $\mathrm{Sb}$, $\mathrm{SbCl}$ and SbS groups) increased the Vickers microhardness values of
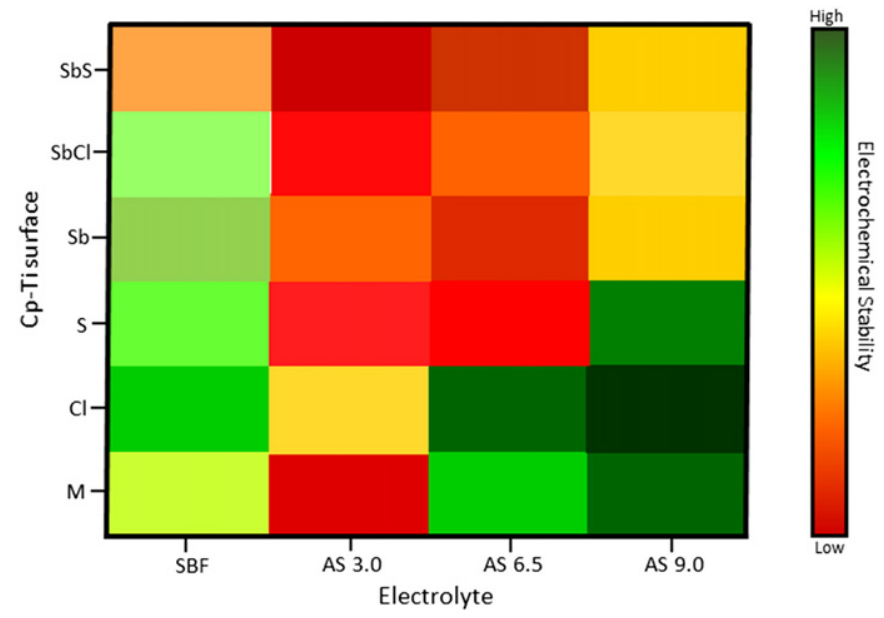

Fig. 5. Corrosion map of $\mathrm{cp}-\mathrm{Ti}$ as a function of surface treatment and electrolyte. SBF ( simulated body fluid) and AS (artificial saliva).

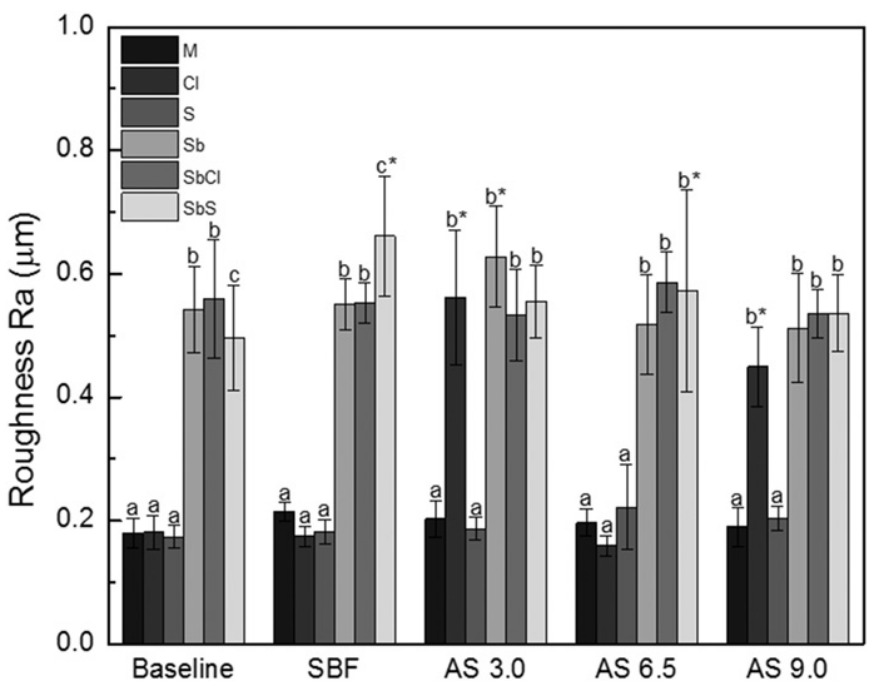

Fig. 6. Roughness data ( $\mathrm{Ra}$ ) of machined and treated cp-Ti discs before and after corrosion in different electrolytes. $(n=5)$ Different lowercase letters represent statistical difference among cp-Ti surfaces within each electrolyte type. *denotes statistical difference of the corroded samples from its corresponding baseline.

cp-Ti surface and a reduction of such values was noted after corrosion process (Fig. 7). At baseline, SbS and $\mathrm{Cl}$ groups had the greatest and lowest surface free energy values, respectively $(p<0.05)$. After corrosion process, the surface free energy increased for all groups, except for SbS where a reduction was noted $(p<0.05)$ (Fig. 8).

AFM was used to provide two- and three-dimensional images of the cp-Ti topography (Fig. 9). All surfaces were free of cracks, densely packed, and composed of visible granules, which was confirmed by the topographic image of discs profile. Few numbers of pits were found in the two-dimensional images of the acid-etched discs although the surface was more uniform and homogenous than the sandblasted samples. The $\mathrm{Al}_{2} \mathrm{O}_{3}$ sandblasting generated deeper valleys and higher peaks on disc surface. Corrosion did not promoted noticeable alteration of the cp-Ti discs (data not showed).

The SEM images showed homogeneity of the samples with no cracks, good adhesion between film and substrate, film continuity, and homogeneous surface morphology (Fig. 10). Longitudinal grooves were observed on the surface of machined samples subjected to acid

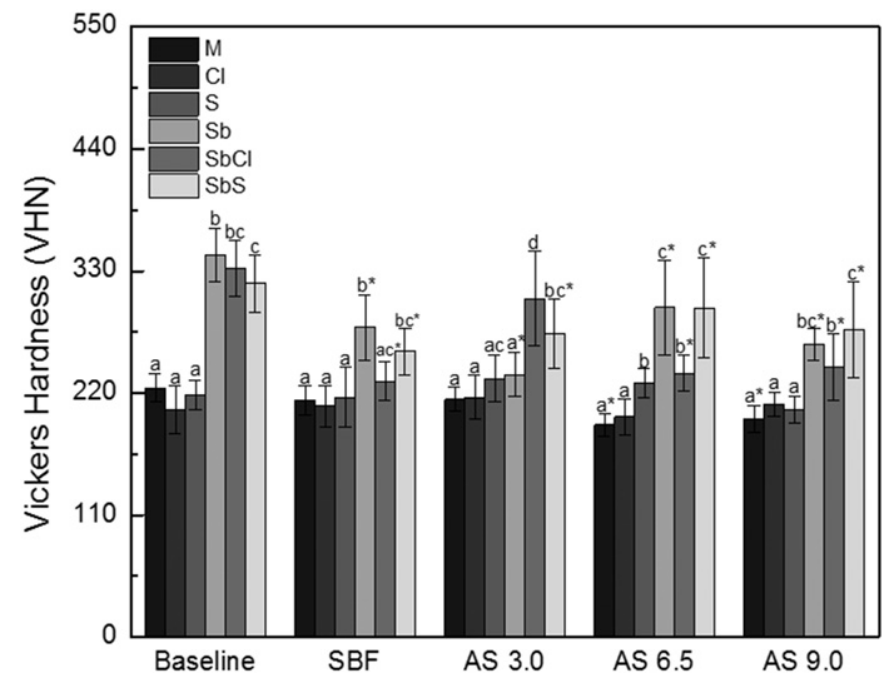

Fig. 7. Vickers microhardness data of machined and treated cp-Ti discs before and after corrosion in different electrolytes. $(n=5)$ Different lowercase letters represent statistical difference among cp-Ti surfaces within each electrolyte type. *denotes statistical difference of the corroded samples from its corresponding baseline. 


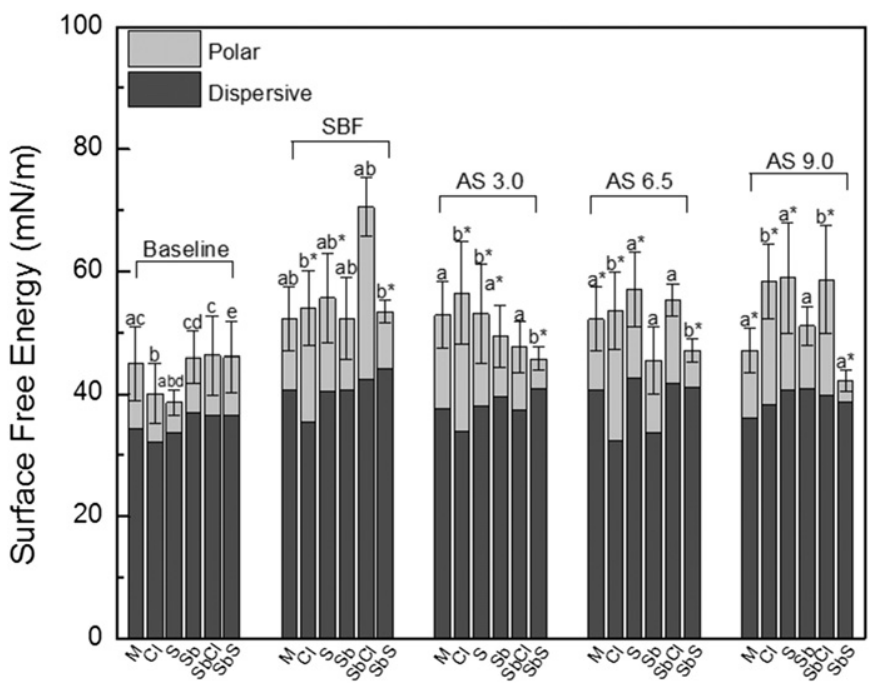

Fig. 8. Surface free energy values of machined and treated cp-Ti discs before and after corrosion in different electrolytes. $(n=5)$ Different lowercase letters represent statistical difference among $\mathrm{cp}$-Ti surfaces within each electrolyte type. *denotes statistical difference of the corroded samples from its corresponding baseline.

etching or not as a consequence of polishing procedure. The acid etching did not generate visible pores/pits. The groups treated with $\mathrm{Al}_{2} \mathrm{O}_{3}$ sandblasting showed cp-Ti surface alteration with deposition of oxide crystals with uniform shape and size. The chemical composition of the $\mathrm{cp}$-Ti surface was measured by EDS. The $\mathrm{M}, \mathrm{Cl}$ and $\mathrm{S}$ groups expressed carbon (C) and titanium (Ti), and the $\mathrm{Sb}, \mathrm{SbCl}$ and $\mathrm{SbS}$ expressed C, Ti, aluminum (Al) and oxygen (O) (Fig. 10). No alteration in the SEM and EDS analyses was noted after corrosion process (data not shown).

The crystalline composition, types and phases of oxides formed on cp-Ti surface were analyzed through XRD. Fig. 11 shows that all groups presented titanium amorphous phase. Groups treated with $\mathrm{Al}_{2} \mathrm{O}_{3}$ ( $\mathrm{Sb}$, $\mathrm{SbCl}$ and $\mathrm{SbS}$ ) presented peaks of corundum (i.e. crystalline form of $\mathrm{Al}_{2} \mathrm{O}_{3}$ ). After corrosion, the same crystalline structures were noted (data not showed).

\section{Discussion}

The major novelty and importance of this study relies on the investigation of the influence of different surface treatments and electrolyte composition on the electrochemical stability of dental implants. It is considered an integrated approach to mimic the oral environment combining surface features able to display enhanced electrochemical resistance and improved osseointegration ability for dental implant applications.

Based on the data of this study, our first research hypothesis was accepted. Sandblasting procedure impaired the corrosion behavior of $\mathrm{cp}-$ Ti. SbS group presented the lowest values of $R_{p}$ and the highest values of $\mathrm{Q}$ in all evaluated electrolytes. On the other hand, acid etching improved the electrochemical stability of cp-Ti.

The SbS group involves a sandblasting treatment with large grit particles and subsequently $\mathrm{H}_{2} \mathrm{SO}_{4}$ etching. The sandblasting procedure increases the surface activity of $\mathrm{Ti}$, promoting an oxide layer with reduced integrity and thickness [43]. Additionally, the increased surface area and surface free energy of sandblasted samples may be another driven force toward reduced corrosion resistance. Similar results were found by Zhang et al. [36] where sandblasting and SLA treatment with $\mathrm{SiO}_{2}$ particles and a mixture of $\mathrm{H}_{2} \mathrm{SO}_{4} / \mathrm{HCl}$ reduced the corrosion resistance of Ti-10Cu sintered alloy. On the other hand, Richard et al. [44] observed that corrosion resistance of $\mathrm{cp}$-Ti increased when coated with $\mathrm{Al}_{2} \mathrm{O}_{3} / \mathrm{TiO}_{2}$ nanoparticles.

Surface etching occurs when a strong acid like sulfuric acid dissolve the titanium oxide layer and hydrogen ions are released, creating pits of various dimensions [45]. These hydrogen ions can somehow interact with aluminum decreasing the corrosion resistance. Besides, it is possible to visualize through AFM images that $S$ group treatment creates largely pores when compared to $\mathrm{Cl}$ group. According to Barranco et al. [46] the roughness alters the capacitance values, and a larger effective surface area gives a higher capacitance values leading to major susceptibility to pitting corrosion.

Etching seems to be a simple and effective technique and has been investigated [27], and it is commonly used to clean and decontaminate Ti surface [23,24]. In our study, the acid etching treatment improved the corrosion behavior of $\mathrm{cp}-\mathrm{Ti}$, mainly the one treated with $\mathrm{HCl} / \mathrm{H}_{2} \mathrm{O}_{2}(\mathrm{Cl}$ group). The formation of an oxide layer of $\mathrm{TiO}_{2}$ onto the Ti surface is directly related to biocompatibility [47] and corrosion resistance [48]. These oxide layers provide porosity to the Ti surface allowing osseointegration and providing stability to the implant [49]. The $\mathrm{TiO}_{2}$ layer is inactive in the biological environment, however it can be destroyed during movements between implant and bone tissue leading to a leak of metallic particles or ions to the living tissues [50]. According to Jonasova et al. [51] during the acid etching treatment, the $\mathrm{HCl}$ acid degrades the oxide film, and the Ti reacts with the acid forming the titanium hydride $\left(\mathrm{TiH}_{2}\right)$ molecule. Top of this layer a new oxide layer can be formed in contact with air, which creates a more stable oxide film. This may explain the greater corrosion stability of $\mathrm{cp}$-Ti etched with $\mathrm{HCl}$ in the present study.

Several authors [27-29,52] have investigated the effect of $\mathrm{HCl} / \mathrm{H}_{2} \mathrm{O}_{2}$ treatment on the peri-implant bone formation. The osteoblastic response was improved for $\mathrm{HCl} / \mathrm{H}_{2} \mathrm{O}_{2}$ etched surface when compared to sandblasted one [52]. Contradicting our results, Faverani et al [53] observed that double acid-etched reduced the corrosion stability of $\mathrm{Ti}-6 \mathrm{Al}-4 \mathrm{~V}$ alloy in SBF containing different concentrations of dextrose and lipopolysaccharide versus machined surface. The authors used a combination of nitric, sulfuric and hydrochloric acid to treat the Ti surface that differs from our etching protocol. Additionally, the total surface area of the etched samples was higher than those observed herein. Such factors may explain the contradictory results.

Depassivation zones were noted for the sandblasted groups in the potentiodynamic curves. According to Szesz et al. [54] sandblasting procedure forms numerous defects onto the Ti surface. The higher the number of defects at the surface, the more the nucleation sites for the formation of defective passive layer [55]. The non-uniform surface caused by sandblasting method creates irregular surface roughening, and some regions are more susceptible do oxidation. After the passive layer is established, saliva ions can degrade the oxide layer, dominating the corrosion process [54].

Regarding the electrolyte solution, artificial saliva at pH 3 impaired the corrosion stability of cp-Ti. Therefore, our second hypothesis was accepted. High values of $\mathrm{I}_{\text {corr }}$ and lower values of $\mathrm{E}_{\text {corr }}$ were noted for samples immersed in acidic medium. Vasilescu et al. [56] evaluated the corrosion resistance of $\mathrm{Ti}-10 \mathrm{Zr}-5 \mathrm{Ta}-5 \mathrm{Nb}$ alloy in Ringer's solution with different pH levels (2.33, 7.1 and 9.1) and found improved corrosion resistance in neutral Ringer's solution. Barao et al. [9] observed reduced corrosion resistance of machined cp-Ti (grade II) and $\mathrm{Ti}-6 \mathrm{Al}-4 \mathrm{~V}$ alloy in acidic artificial saliva medium. Nevertheless, Abey et al. [57] reported that neutral pHs (6.5 and 7.5) of artificial saliva mitigate the electrochemical stability of machined cp-Ti (grade I).

The presence of irregularities and porosities on the oxide layer of cpTi after exposure in acidic medium explain the reduced corrosion resistance [58]. According to previous studies $[59,60]$ the protective oxide film formed in acidic environment is degraded, which accelerates the ions exchange between Ti surface and electrolyte [9]. Therefore, the protectiveness of the oxide film is reduced at low $\mathrm{pH}[60,61]$ and may explain the high corrosion activity observed in artificial saliva at $\mathrm{pH} 3$.

It has been shown that the corrosion process can induce the release of metals ions into the body [62]. Olmedo et al. [63] reported two cases of reactive lesions in the peri-implant mucosa due to the release of $\mathrm{Ti}$ fragments and corrosive process on the surface of the implant prosthetic 

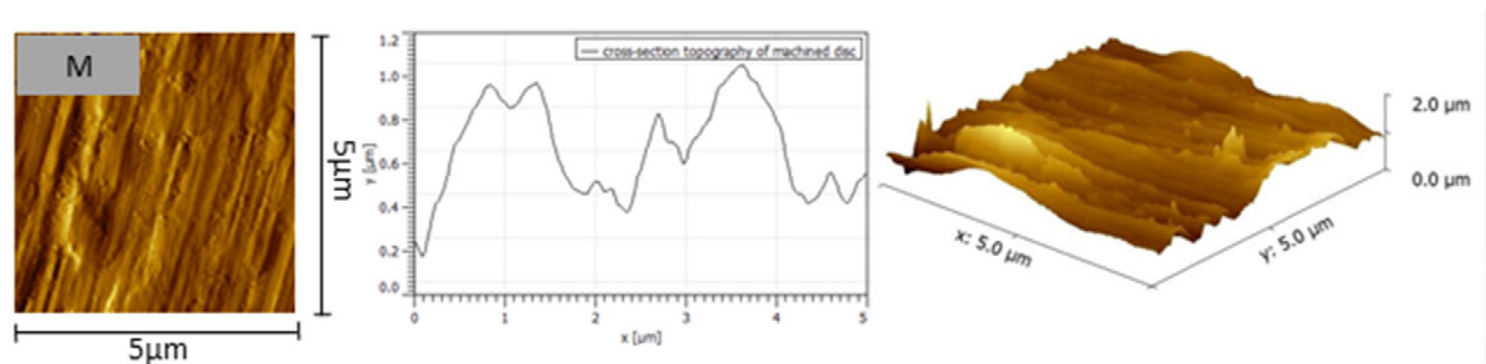

$2.0 \mu \mathrm{m}$
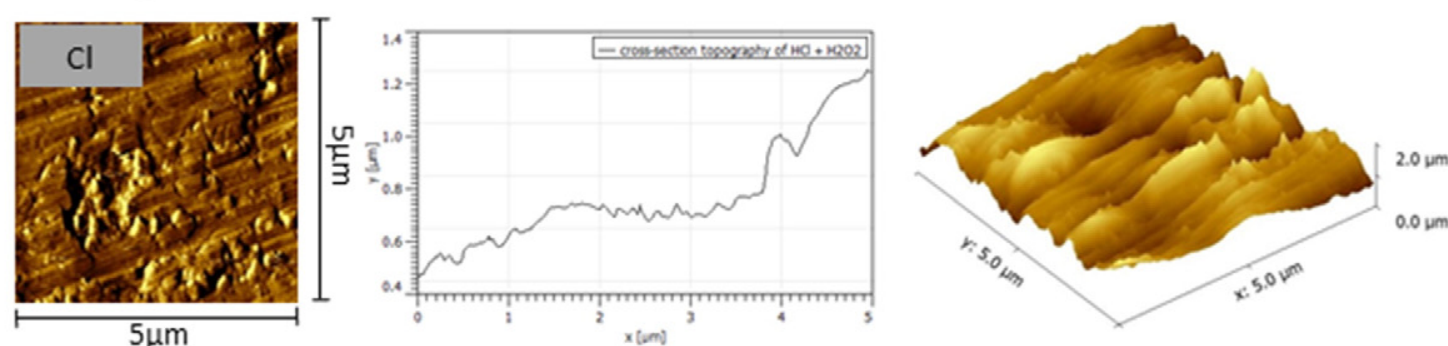

$-1.8$

$-1.6$

$-1.4$
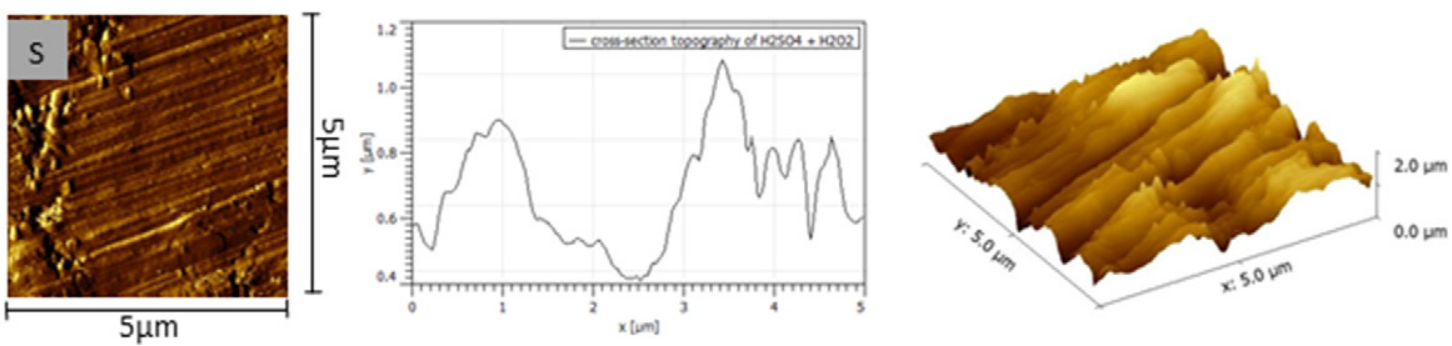

$-1.2$

$-1.0$

$-0.8$

$-0.6$

$-0.4$

$-0.2$
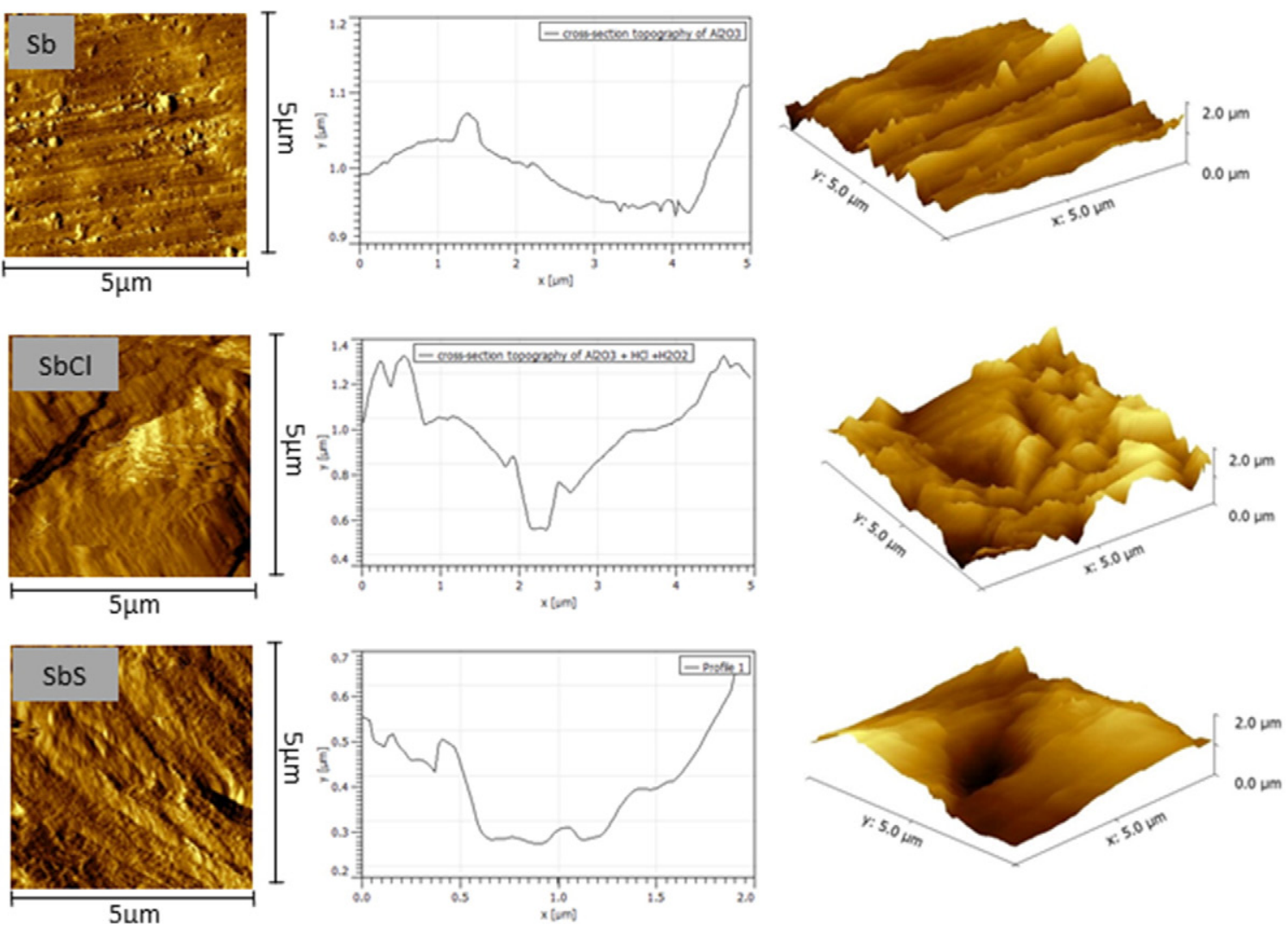

Fig. 9. AFM 2D and 3D images of topographic and profiles of all studied surfaces: $\mathrm{M}-$ machined; $\mathrm{Cl}-\mathrm{HCl}+\mathrm{H}_{2} \mathrm{O}_{2} ; \mathrm{S}_{-}-\mathrm{H}_{2} \mathrm{SO}_{4}+\mathrm{H}_{2} \mathrm{O}_{2} ; \mathrm{Sb}-\mathrm{Al}_{2} \mathrm{O}_{3} ; \mathrm{SbCl}-\mathrm{Al} \mathrm{O}_{3}+\mathrm{HCl}+\mathrm{H}_{2} \mathrm{O}_{2}$; $\mathrm{SbS}-\mathrm{Al}_{2} \mathrm{O}_{3}+\mathrm{H}_{2} \mathrm{SO}_{4}+\mathrm{H}_{2} \mathrm{O}_{2}$ 

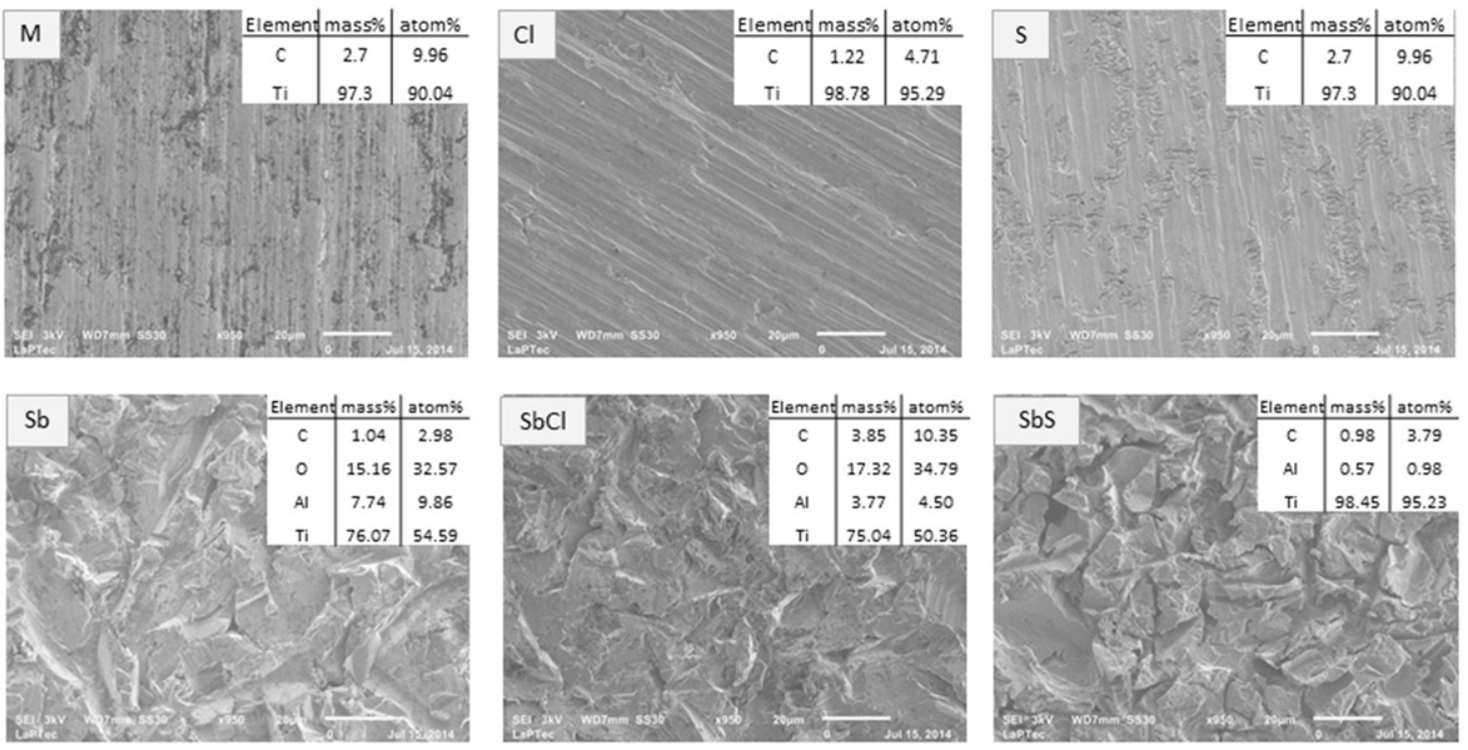

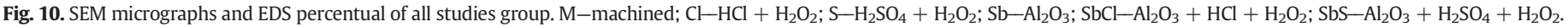

platform. Hallam et al. [64] investigated patients with titanium hip replacements who complained about pain despite well-fixed and aseptic prosthesis. The authors found that the $\mathrm{pH}$ in the region of the prosthesis was highly acid with visible evidence of corrosion.

The release of $\mathrm{Al}_{2} \mathrm{O}_{3}$ particles from the $\mathrm{cp}$-Ti surface is probably become the substantial risk for human healthy. In fact, dental implants with enhanced roughness are more likely to detach during the surgical insertion into the bone [65]. In this study, sandblasted discs showed the highest roughness in contrary to machined group. According to Senna et al. [65] during the implant insertion some particles can be released at the implant/bone interface, which is associated with the roughness surface and some particles can be removed from the implant site after phagocytosis by macrophages [66]. However, according to Schliephake et al. [66], Ti surface modification such as sandblasted and etched surfaces may minimize the abrasion from fixture surfaces while providing a biologically favorable surface structure. Several studies [67-69] evaluated the beneficial effect of rough surface obtained by sandblasting procedure on osseointegration process. The sandblasting procedure is a strong mechanism of $\mathrm{Al}_{2} \mathrm{O}_{3}$ particles incorporation on the surface.

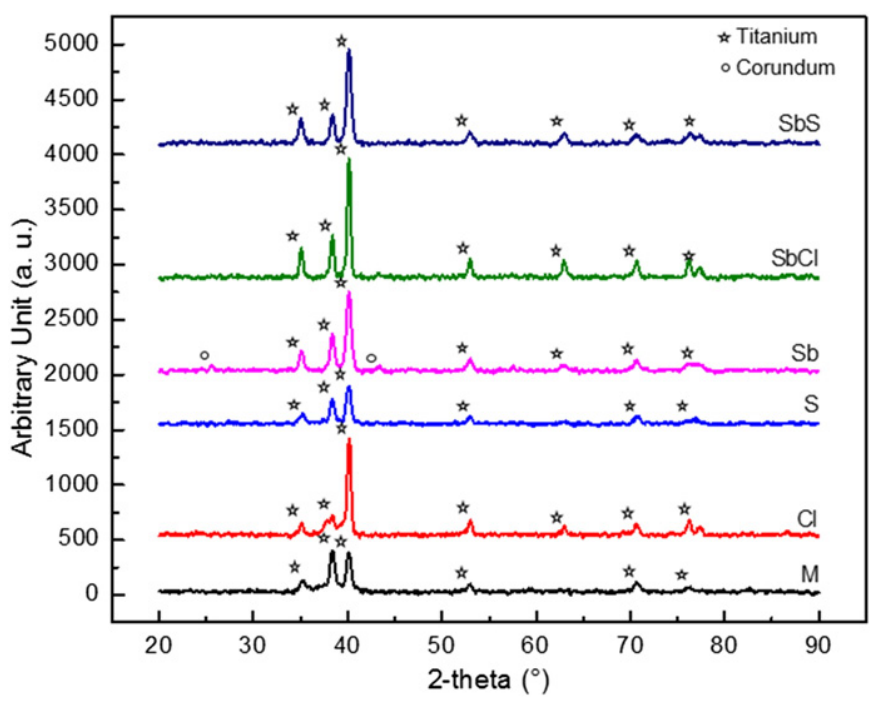

Fig. 11. XRD pattern obtained from machined and treated cp-Ti discs.
Following the well-established protocol for surgical procedures of dental implants insertion can minimize the release of $\mathrm{Al}_{2} \mathrm{O}_{3}$ particles to human body.

The biocompatibility of dental implants is directly related to their corrosion behavior. The high corrosion resistance of Ti results from the formation of a dense and stable layer of $\mathrm{TiO}_{2}$ on its surface [48]. EIS data showed that a protective layer was formed on the surface of the discs in all evaluated electrolytes, but the stability of these films differs among groups. In the sandblasted groups ( $\mathrm{Sb}, \mathrm{SbCl}$ and $\mathrm{SbS}$ ), it was possible to observe depassivation zones at high electrode potential values. According to Meakin et al. [70] depassivation zone could be explained by the accumulation of corrosion products in the pits formed after corrosion process, thereby increasing osmotic pressure inside of it.

The biocompatibility is also a critical factor for the osseointegration process of dental implants, and depends on the physical and chemical properties of the surface, such as roughness, hardness, surface free energy and chemical composition. In this paper, surface characterization of cp-Ti was performed at two time points in order to understand the influence of corrosion process on the degradation mechanism of the surface. Increased surface roughness was observed in all sandblasted groups ( $\mathrm{Sb}, \mathrm{SbCl}$ and $\mathrm{SbS}$ ). According to Buser et al. [67] the surface roughness obtained after SLA treatment enhance the osteoconductive process, bone to implant contact and increase removal torque. However, Zhang et al. [36] observed that after sandblasting and SLA treatments, a rough surface was formed, but the corrosion resistance was reduced and there was an increase in the $\mathrm{Ti}$ and $\mathrm{Cu}$ ion release. Corrosion can also lead to a rougher surface, weakening mechanical stability of the implant, release of metal ions to the surrounding tissues, leading to adverse tissue reaction and increasing the toxicity to immune reactions [61]. Rougher surfaces can also promote more microorganism adhesion and facilitate the colony formation and leading to biofilm growth [71].

The sandblasting treatment increased the Vickers microhardness of cp-Ti. A previous study also showed higher microhardness in treated cp-Ti than in polished samples [47]. The lattice deformation caused by sandblasting may explain these results. The transfer of hard particles deformed plastically the ductile material surface, producing a nonuniform strain in the lattice [54]. Clinically, the hardness of Ti surface is a positive property for dental and orthopedic implants submitted to excessive loading [47]. Herein, acid etching did not change the Vickers microhardness of $\mathrm{cp}$-Ti when compared to the machined surface. On the other hand, Faverani et al. [53] found that double acid etching (nitric, sulfuric and hydrochloric acids) increased the Vickers 
microhardness of Ti-6Al-4V alloy. Differences in the bulk material and acid type may explain the contradicting results.

After the corrosion process, the Vickers microhardness values of sandblasted groups decreased. The release of $\mathrm{Al}_{2} \mathrm{O}_{3}$ particles from the cp-Ti surface to the electrolyte may reduce the thickness of the coating, which explains the reduction of Vickers microhardness after corrosion process. Such phenomenon can limit the fatigue life and ultimate strength of the material, leading to mechanical failure of dental implants [61].

Gentleman et al. [72] described the surface free energy as a fundamental property of the material surface that will govern the first interactions with the biological environment. Increased cell proliferation has been showed in materials with greater surface wettability [73] and the polar component seems to be more determinant for cellular adhesion strength [74]. At baseline, the samples treated with $\mathrm{Al}_{2} \mathrm{O}_{3}$ sandblasting and further acid etching with $\mathrm{H}_{2} \mathrm{SO}_{4}+\mathrm{H}_{2} \mathrm{O}_{2}$ presented higher surface free energy, which improves the interaction between implant and surrounding bone [75]. However, Carvalho et al. [76] revealed that treatment with $\mathrm{HCl} / \mathrm{H}_{2} \mathrm{SO}_{4}$ on $\mathrm{cp}$-Ti surface did not exhibit cytocompatibility and also inhibited cell proliferation and osteoblast expression. The higher surface energy for SbS group suggested a link between surface hydrocarbons and the hydrophilicity of titanium. Oxygen species derived from $\mathrm{O}_{2}$ under air, which effectively increase hydrophilicity, are covered by hydrocarbon adsorption [77]. On the other hand, the $\mathrm{Cl}$ group, at baseline, presented the lowest surface free energy values and surface roughness seems to be determinant of surface wettability [78]. Taborelli et al. [79] also explain the initial hydrophobicity of etched samples by the topography generated by the acid attack treatment.

In our study, the corrosion process increased the surface free energy of acid etching $\mathrm{cp}-\mathrm{Ti}(\mathrm{Cl}$ and $\mathrm{S}$ groups) while a reduction was noted for sandblasted ones ( $\mathrm{Sb}, \mathrm{SbCl}$ and $\mathrm{SbS}$ groups). When the implant micromorphology is altered, in vitro tests showed that the surface energy is also modified, thereby potentially affecting in vivo cell migration, proliferation and cellular activity $[80,81]$. Ti and its alloys are subjected to electrochemical reactions and leading to corrosion process, which leads to gradual surface degradation of the surface material by oxidation process $[61,82]$. The corrosion process altered the morphology of sandblasted groups possibly affecting the surface free energy values, especially the polar component, indicating more hydrophobic surface. However, the relationship between surface alteration and surface free energy needs further investigations.

Sandblasting associated with acid etching creates macro- and microroughness on sample surface. This characteristic was confirmed by the two- and three-dimensional images of SEM and AFM, revealing slighter roughness on discs treated with acid etching compared to the sandblasted samples. Also, the EDS analysis showed the presence of carbon in all surface treatments. The deposition of hydrocarbons into Ti surfaces is inevitable [83]. Morra et al. [83] analyzed the chemical composition of several types of commercially available implants and found $17.9 \%$ to $76.5 \%$ carbon deposition on 34 different implants. It indicates that such adsorption is regardless of topography, suggesting that hydrocarbon deposition may occur on Ti-based materials with any modified surface.

In terms of XRD peaks, there was no difference in XRD patterns between the surface treatments samples, indicating that these treatments were amorphous or poorly nano crystallized. The formation of these crystalline forms is found to be strictly associated with temperature and concentration [84]. It was reported that either amorphous or nano crystalline coatings contributed to further enhancing corrosion resistance of metal substrates, compared to coatings with coarse crystalline structure [85].

In the present study, only electrochemical parameters were evaluated and no masticatory loading was performed. In this way, future studies linking the corrosion behavior mechanisms with wear in tribology studies are necessary in order to simulate the complex oral environment. Besides, in dentistry, the clinical implications of the corrosive nature of dental implants is still limited, thereby multidisciplinary studies are necessary in order to understand the role of corrosion on implants longevity and failure.

In summary, this study showed that the surface treatment of dental implants and the condition of the oral environment has significant influence on the electrochemical behavior and mechanical properties of cp-Ti. Based on our results, etching with $\mathrm{HCl}$ and $\mathrm{H}_{2} \mathrm{O}_{2}$ seems to be an effective technique to modify Ti surface, due to its improved corrosion behavior in all electrolytes evaluated as well as good surface characteristics after the corrosion process. Our results also provided important inside about the higher in vivo success rate of dental implants treated with acid etching when compared to machined and sandblasted ones [86-88]. Therefore, in a nutshell, the lower corrosion stability of sandblasted surfaces may be a driven force toward increased failure of dental implants in a clinical scenario.

\section{Conclusion}

Based on the results of this study, the following conclusions can be drawn:

- Acid etching with $\mathrm{HCl}$ improved the electrochemical stability of cp-Ti.

- Although sandblasted treatment improved the structural and mechanical properties of $\mathrm{cp}-\mathrm{Ti}$, reduced corrosion resistance was noted.

- Acidic medium impaired the corrosion behavior of cp-Ti.

- Sandblasting procedure increased the roughness, Vickers microhardness and surface free energy values of cp-Ti.

- After the corrosion process, there was a decrease in Vickers microhardness and surface free energy values of sandblasted cp-Ti.

\section{Acknowledgments}

The authors thank the State of Sao Paulo Research Foundation (FAPESP) (grants 2013/24112-2 and 2013/08451-1) for financial support, Rafael Parra for his contribution and support in the Plasma Technology Lab at Univ Estadual Paulista (UNESP) and Elton José de Souza from the Department of Physics and Chemistry at UNESP for the AFM facility. The funder had no role in study design, data collection and analysis, decision to publish, or preparation of the manuscript.

\section{References}

[1] S. Annibali, M.P. Cristalli, D. Dell'Aquila, I. Bignozzi, G. La Monaca, A. Pilloni, J. Dent Res. 91 (2012) 25-32.

[2] W. Slot, G.M. Raghoebar, A. Vissink, J.J. Huddleston Slater, H.J. Meijer, J. Clin Periodontol. 37 (2010) 98-110.

[3] M.B. Lewis, I. Klineberg, Aust. Dent. J. 56 (2011) 181-192.

[4] M. Cortada, L.L. Giner, S. Costa, F.J. Gil, D. Rodriguez, J.A. Planell, J. Mater. Sci. Mater. Med. 11 (2000) 287-293.

[5] A.C. Vieira, A.R. Ribeiro, L.A. Rocha, J.P. Celis, Wear 261 (2006) 994-1001.

[6] A. Abdal-Hay, A.S. Hamdy, K.A. Khalil, J.H. Lim, Mater. Sci. Eng. C Mater. Biol. Appl. 49 (2015) 681-690.

[7] N. Horasawa, T. Yamashita, S. Uehara, N. Udagawa, Mater. Sci. Eng. C Mater. Biol Appl. 46 (2015) 86-96.

[8] V.A. Barao, M.T. Mathew, W.G. Assuncao, J.C. Yuan, M.A. Wimmer, C. Sukotjo, J. Dent Res. 90 (2011) 613-618.

[9] V.A. Barao, M.T. Mathew, W.G. Assuncao, J.C. Yuan, M.A. Wimmer, C. Sukotjo, Clin. Oral Implants Res. 23 (2012) 1055-1062.

[10] F. Yu, O. Addison, S.J. Baker, A.J. Davenport, Int. J. Oral Sci. (2015).

[11] F. Nikolopoulou, Implant. Dent. 15 (2006) 372-376.

[12] S. Murrell, T.A. Marshall, P.J. Moynihan, F. Qian, J.S. Wefel, J. Dent. 38 (2010) 284-289.

[13] Y.M. Dong, E.I. Pearce, L. Yue, M.J. Larsen, X.J. Gao, J.D. Wang, Caries Res. 33 (1999) 428-436.

[14] B.L. Gregory-Head, D.A. Curtis, L. Kim, J. Cello, J. Prosthet. Dent. 83 (2000) 675-680.

[15] R.L. Messer, G. Tackas, J. Mickalonis, Y. Brown, J.B. Lewis, J.C. Wataha, J. Biomed. Mater. Res. B Appl. Biomater. 88 (2009) 474-481.

[16] R.A. Gittens, R. Olivares-Navarrete, R. Tannenbaum, B.D. Boyan, Z. Schwartz, J. Dent. Res. 90 (2011) 1389-1397.

[17] K. Gotfredsen, T. Berglundh, J. Lindhe, Clin. Oral Implants Res. 12 (2001) 196-201. 
[18] A. Lin, C.J. Wang, J. Kelly, P. Gubbi, I. Nishimura, Int. J. Oral Maxillofac. Implants 24 (2009) 808-816.

[19] A. Wennerberg, T. Albrektsson, Clin. Oral Implants Res. 20 (2009) 172-184.

[20] P. Trisi, R. Lazzara, A. Rebaudi, W. Rao, T. Testori, S.S. Porter, J. Periodontol. 74 (2003) 945-956.

[21] P.S. Pai, M.T. Mathew, M.M. Stack, L.A. Rocha, Tribol. Int. 41 (2008) 672-681.

[22] F.J.C. Braga, R.F.C. Marques, E.D.A. Filho, A.C. Guastaldi, Appl. Surf. Sci. 253 (2007) 9203-9208.

[23] D.L. Cochran, R.K. Schenk, A. Lussi, F.L. Higginbottom, D. Buser, J. Biomed. Mater. Res. 40 (1998) $1-11$.

[24] A. Jemat, M.J. Ghazali, M. Razali, Y. Otsuka, Biomed. Res. Int. 2015 (2015) 791725

[25] J. Pan, H. Liao, C. Leygraf, D. Thierry, J. Li, J. Biomed. Mater. Res. 40 (1998) 244-256.

[26] O. Pop-Georgievski, D. Kubies, J. Zemek, N. Neykova, R. Demianchuk, E.M. Chánová, Bilisten J. Nanotechnol. 6 (2015) 617-631.

[27] G.S. Shi, L.F. Ren, L.Z. Wang, H.S. Lin, S.B. Wang, Y.Q. Tong, Oral Surg. Oral Med. Oral Pathol. Oral Radiol. Endod. 108 (2009) 368-375.

[28] G.L. Yang, F.M. He, X.F. Yang, X.X. Wang, S.F. Zhao, Oral Surg. Oral Med. Oral Pathol. Oral Radiol. Endod. 106 (2008) 516-524.

[29] F.M. He, G.L. Yang, Y.N. Li, X.X. Wang, S.F. Zhao, Int. J. Oral Maxillofac. Surg. 38 (2009) $677-681$.

[30] K. Anselme, Biomaterials 21 (2000) 667-681.

[31] C.Y. Guo, J.P. Matinlinna, A.T. Tang, Int. J. Biomater. 2012 (2012) 381535.

[32] C.Y. Guo, J.P. Matinlinna, T.H. Tang, J. Adhes. Sci. Technol. 26 (2012) 2603-2613.

[33] S. Li, J. Ni, X. Liu, X. Zhang, S. Yin, M. Rong, Z. Guo, L. Zhou, J. Biomed. Mater. Res. B Appl. Biomater. 100 (2012) 1587-1598.

[34] T. Albrektsson, A. Wennerberg, Int. J. Prosthodont. 17 (2004) 536-543.

[35] T. Albrektsson, A. Wennerberg, Int. J. Prosthodont. 17 (2004) 544-564.

[36] E. Zhang, C. Liu, Biomed. Mater. 10 (2015) 045009.

[37] L.F. Faverani, J.F. Fogaça, T. Machado, E.A. Silva, V.A.R. Barão, W.G. Assunção, J. BioTribo-Corros. (2015)

[38] D. Li, B. Liu, Y. Han, K. Xu, Implant. Dent. 10 (2001) 59-64.

[39] A. Nanci, J.D. Wuest, L. Peru, P. Brunet, V. Sharma, S. Zalzal, M.D. McKee, J. Biomed. Mater. Res. 40 (1998) 324-335.

[40] L. Muller, F.A. Muller, Acta Biomater. 2 (2006) 181-189.

[41] M.T. Mathew, V.A. Barao, J.C. Yuan, W.G. Assuncao, C. Sukotjo, M.A. Wimmer, J. Mech. Behav. Biomed. Mater. 8 (2012) 71-85.

[42] J.B. Jorcin, M.E. Orazem, N. Pebere, B. Tribollet, Electrochim. Acta 51 (2006) 1473-1479.

[43] B.I. Johansson, B. Bergman, Dent. Mater. 11 (1995) 41-46.

[44] C. Richard, C. Kowandy, J. Landoulsi, M. Geetha, H. Ramasawmy, Int. J. Refract. Met Hard 28 (2010) 115-123.

[45] S. Szmukler-Moncler, M. Bischof, R. Nedir, M. Ermrich, Clin. Oral Implants Res. 21 (2010) 944-950

[46] V. Barranco, M.L. Escudero, M.C. Garcia-Alonso, Electrochim. Acta 52 (2007) 4374-4384.

[47] C.H. Yang, Y.T. Wang, W.F. Tsai, C.F. Ai, M.C. Lin, H.H. Huang, Clin. Oral Implants Res. 22 (2011) 1426-1432.

[48] E. Tamam, I. Turkyilmaz, J. Oral Implantol. 40 (2014) 153-159.

[49] S.E. Wheelis, I.M. Gindri, P. Valderrama, T.G. Wilson Jr., J. Huang, D.C. Rodrigues, Clin Oral Implants Res. (2015).

[50] S. Mändl, R. Sader, G. Thorwarth, D. Krause, H.-F. Zeilhofer, H.H. Horch, B. Rauschenbach, Nucl. Inst. Methods Phys. Res. B 206 (2003) 517-521.

[51] L. Jonasova, F.A. Muller, A. Helebrant, J. Strnad, P. Greil, Biomaterials 25 (2004) 1187-1194.

[52] F. Zhang, C.F. Zhang, M.N. Yin, L.F. Ren, H.S. Lin, G.S. Shi, Med. Sci. Monit. 18 (2012) BR265-BR272.

[53] L.P. Faverani, W.G. Assuncao, P.S. de Carvalho, J.C. Yuan, C. Sukotjo, M.T. Mathew, V.A. Barao, PLoS One 9 (2014) e93377.

[54] G.d.S.E.M. Szesz, G.G. de Lima, B.A. da Silva, N.K. Kuromoto, C.M. Lepienski, J. Mater. Sci. Mater. Med. (2014) 2265-2275.
[55] T. Hu, Y.C. Xin, S.L. Wu, C.L. Chu, J. Lu, L. Guan, H.M. Chen, T.F. Hung, K.W.K. Yeung, P.K. Chu, Mater. Chem. Phys. 126 (2011) 102-107.

[56] E. Vasilescu, P. Drob, D. Raducanu, V.D. Cojocaru, I. Cinca, D. Iordachescu, R. Ion, M. Popa, C. Vasilescu, J. Mater. Sci. Mater. Med. 21 (2010) 1959-1968.

[57] S. Abey, M.T. Mathew, D.J. Lee, K.L. Knoernschild, M.A. Wimmer, C. Sukotjo, J. Oral Implantol. 40 (2014) 3-10.

[58] S.L. de Assis, S. Wolynec, I. Costa, Electrochim. Acta 51 (2006) 1815-1819.

[59] M. Nakagawa, S. Matsuya, K. Udoh, Dent. Mater. J. 21 (2002) 83-92.

[60] M.E. Souza, L. Lima, C.R. Lima, C.A. Zavaglia, C.M. Freire, J. Mater. Sci. Mater. Med. 20 (2009) 549-552.

[61] P. Patil, O.P. Kharbanda, R. Duggal, T.K. Das, D. Kalyanasundaram, Am. J. Orthod. Dentofacial 147 (2015) S88-S100.

[62] M. Simon, C. Lagneau, J. Moreno, M. Lissac, F. Dalard, B. Grosgogeat, Eur. J. Oral Sci. 113 (2005) 537-545.

[63] D.G. Olmedo, M.L. Paparella, M. Spielberg, D. Brandizzi, M.B. Guglielmotti, R.L. Cabrini, J. Periodontol. 83 (2012) 973-980.

[64] P. Hallam, F. Haddad, J. Cobb, J. Bone Joint Surg. Br. Vol. 86 (2004) 27-30.

[65] P. Senna, A. Antoninha Del Bel Cury, S. Kates, L. Meirelles, Clin. Implant. Dent. Relat. Res. 17 (2015) 681-692.

[66] H. Schliephake, G. Reiss, R. Urban, F.W. Neukam, S. Guckel, Int. J. Oral Maxillofac. Implants 8 (1993) 502-511.

[67] D. Buser, R.K. Schenk, S. Steinemann, J.P. Fiorellini, C.H. Fox, H. Stich, J. Biomed. Mater. Res. 25 (1991) 889-902.

[68] H.J. Lee, J. Lee, J.T. Lee, J.S. Hong, B.S. Lim, H.J. Park, Y.K. Kim, T.I. Kim, J. Periodontal Implant Sci. 45 (2015) 120-126.

[69] L. Salou, A. Hoornaert, G. Louarn, P. Layrolle, Acta Biomater. 11 (2015) 494-502.

[70] P. Meakin, T. Jossang, J. Feder, Phys. Rev. E Stat. Phys. Plasmas Fluids Relat. Interdiscip. Top. 48 (1993) 2906-2916.

[71] T.D. Morgan, M. Wilson, J. Appl. Microbiol. 91 (2001) 47-53.

[72] M.M. Gentleman, E. Gentleman, Int. Mater. Rev. 59 (2014) 417-429.

[73] G. Altankov, F. Grinnell, T. Groth, J. Biomed. Mater. Res. 30 (1996) 385-391.

[74] N.J. Hallab, K.J. Bundy, K. O'Connor, R.L. Moses, J.J. Jacobs, Tissue Eng. 7 (2001) 55-71.

[75] D.V. Kilpadi, J.E. Lemons, J. Biomed. Mater. Res. 28 (1994) 1419-1425.

[76] D.R. Carvalho, P.S. Carvalho, O. Magro Filho, J.D. de Mello, M.M. Beloti, A.L. Rosa, Braz. Dent. J. 21 (2010) 3-11.

[77] R. Hayashi, T. Ueno, S. Migita, Y. Tsutsumi, H. Doi, T. Ogawa, T. Hanawa, N. Wakabayashi, J. Dent. Res. 93 (2014) 698-703.

[78] F. Rupp, L. Scheideler, D. Rehbein, D. Axmann, J. Geis-Gerstorfer, Biomaterials 25 (2004) 1429-1438.

[79] M. Taborelli, M. Jobin, P. Francois, P. Vaudaux, M. Tonetti, S. Szmukler-Moncler, J.P. Simpson, P. Descouts, Clin. Oral Implants Res. 8 (1997) 208-216.

[80] N. Hori, T. Ueno, H. Minamikawa, F. Iwasa, F. Yoshino, K. Kimoto, M.C. Lee, T. Ogawa, Acta Biomater. 6 (2010) 4175-4180.

[81] S.A. Gehrke, S. Taschieri, M. Del Fabbro, P.G. Coelho, J. Oral Implantol. (2013).

[82] V.A. Barao, C.J. Yoon, M.T. Mathew, J.C. Yuan, C.D. Wu, C. Sukotjo, J. Periodontol. 85 (2014) 1275-1282.

[83] M. Morra, C. Cassinelli, G. Bruzzone, A. Carpi, G. Di Santi, R. Giardino, M. Fini, Int. J. Oral Maxillofac. Implants 18 (2003) 40-45.

[84] Y. Yang, C. Zhang, Y. Peng, Y. Yu, L. Liu, Corros. Sci. 59 (2012) 10-19.

[85] X.L. Cao, T. Sun, Y. Yu, J. Mater. Sci. Mater. Med. 26 (2015) 144.

[86] W. Khang, S. Feldman, C.E. Hawley, J. Gunsolley, J. Periodontol. 72 (2001) 1384-1390.

[87] J.L. Calvo-Guirado, M. Satorres-Nieto, A. Aguilar-Salvatierra, R.A. Delgado-Ruiz, J.E. Mate-Sanchez de Val, J. Gargallo-Albiol, G. Gomez-Moreno, G.E. Romanos, Clin. Oral Investig. 19 (2015) 509-517.

[88] D. Yoo, C. Marin, G. Freitas, N. Tovar, E.A. Bonfante, H.S. Teixeira, M.N. Janal, P.G. Coelho, Implant. Dent. 24 (2015) 256-262. 